\title{
ECO-RELIGIO-CULTURE SUATU ALTERNATIF PENGELOLAAN LINGKUNGAN
}

Husni Thamrin, Zulfan Saam

E=husnithamrin23@gmail.com, husni@yahoo.com, zulfansaam@yahoo.com

PPs UIN Sultan Syarif Kasim Riau

\begin{abstract}
Rapid technological advances, makes progress in all fields and at the same time cause undesirable effects. The impact of technological advances that have become prominent global impact, so the concern of all countries in the world. An environmental impact globalized is not solely due to rapid technological advances, but also induced human

One of the ironies of the development of human civilization is the development and modernization is intended to improve the quality of human life, including indigenous peoples, but it is more often the indigenous peoples who are victims of development and modernization Though indigenous peoples are loaded with the values of local wisdom in preserving the environment life. Local people had a cosmological view of the very high in maintaining a sustainable environment.

Traditional knowledge is a system in the order of social, political, cultural, economic and environmental life in the midst of the local community. Characteristics inherent in traditional wisdom is that it is dynamic, sustainable and acceptable to the community. In local communities, traditional wisdom embodied in the form of a set of rules, knowledge and skills as well as values and ethics that govern the social order that communities continue to thrive from generation to generation. In accordance with customary rules of traditional knowledge which is a system in the order of sociopolitical-cultural-economic and living environment in the middle of the local community. Characteristics inherent in traditional wisdom is that it is dynamic, sustainable and acceptable to the community.

Local wisdom Malays not only in the form of values and customary norms, but also included in the activities and the use of technology. This can be seen as behavior and attitude, everyday, use pickaxe (tool to cut), axes (tool for splitting), lading or machete (a tool for slashing), trowel (tool for weeding), cabak (a tool for reversing land) , sickle (a tool for cutting grass), tembilang (a tool for digging), and others. All of these tools if used, nobody has the potential to damage the environment to the extent that harm.
\end{abstract}

Key word: eco culture, eco religious and environmental. 


\section{PENDAHULUAN}

Pendekatan eco-religio-culture merangkum suatu falsafah pengelolaan sumberdaya, yang mengupayakan produktivitas lewat dukungan ekosistem. Pembangunan berwawasan lingkungan (eco-development) tidak menganjurkan untuk kembali kepada metode produksi yang digunakan oleh nenek moyang. Sistem pembangunan itu memperhatikan sejarah budaya dari berbagai masyarakat tani, keterampilan yang sudah membudaya dikalanganorang biasa, dan eco-religio-culturemenyatakan bahwaorang menghubungkan diri dengan lingkungan alam mereka dengan pendekatan budaya dan nilai nilai agama.Hasil penelitian dan percobaan apapun hanya akan bernilai terapan terbatas apabila tidak melibatkan pelaku utama pembangunan dalam peran yang seharusnya mereka jalankan.

Keberadaan komunitas masyarakat Melayu tradisional dari hari kehari semakin memprihatinkan. Komunitas masyarakat ini adalah komunitas masyarakat yang sangat lemah dan rentan terhadap perubahan. Masyarakat Melayu memiliki komposisi mata pencaharian sebagai petani ladang berpindah-pindah di hutan. Dihutanlah sesungguhnya mereka dapat mempertahankan dirinya, karena di hutan tersedia berbagai fauna dan flora serta sumberdaya alam lainnya seperti air dan tanah untuk keberlangsungan hidup (Husni, 2003). Dewasa ini hutan sebagai tempat mereka hidup hampir dikatakan tidak ada lagi, karena hutan telah beralih fungsi menjadi lahan perkebunan para konglomerat dan eksploitasi minyak diatas pemukiman mereka. Hilangnya hutan ini telah mengakibatkan perubahan lingkungan yang sangat luar biasa. Flora, fauna, air dan hasil-hasil hutan sebagai tempat mereka hidup saat ini sudah sangat terbatas. Masyarakat ini sekarang hidup dalam keadaan marjinaldiakibatkan oleh kebijakan pemerintah yang sentralistik,tidak memperhatikan kearifan lokal, hukum adat, dan tidak mengakui keberadaan hak tanah adat.

Lingkungan hidup merupakan suatu sistem yang terdiri dari sub-sub sistem yang saling menunjang serta bekerja sama dan terikat secara integrasi dalam rangka memenuhi keberlangsungan dari perikehidupan antar makhluk hidup. Manusia merupakan bagian dari lingkungan dan sangat tergantung kepada lingkungan sehingga manusiapun dapat mengubah suatu lingkungan. Perubahan lingkungan oleh manusia ini dapat menimbulkan dampak positif dan negatif dengan interaksi yang sangat kompleks (Surjani,2006). Pengaruh terhadap suatu unsur akan merambat pada unsur lain sehingga pengaruhnya terhadap manusia sering tidak dapat dengan segera terlihat dan terasakan. Jadi, manusia adalah bagian integral dari lingkungan hidupnya, yang tidak dapat terpisahkan.

Masyarakat Melayu dengan lingkungan hutan, sungai, laut dan danau, memiliki fungsi ekologi, ekonomi, dan sosial budaya. Jika kawasan lingkungan di tempat ini mengalami gangguan kestabilan lingkungan, maka gangguan di tempat tersebut juga akan mengalami peningkatan dari waktu ke waktu, sehingga menimbulkan masalah berupa penurunan kualitas sungai, flora dan fauna. Kegiatan yang dilakukan diantaranya disebabkan oleh kebijakan pemerintah dalam memanfaatkan hutan sebagai sumber kehidupan, baik interaksi langsung maupun tidak langsung.

Peningkatan aktifitas manusia di sepanjang aliran sungai, ternyata telah menurunkan kualitas dan kuantitas pada sungai yang ada di Riau.Sebagai gambaran,lahan-lahan yang dahulunya hutan di sepanjang Sungai Rokan kini telah banyak 
Husni Thamrin, Zulfan Saam; ECO-Religio-Culture Suatu Alternatif Pengelolaan Lingkungan

dibuka lahan perkebunan kelapa sawit. Alih fungsi hutan menjadi perkebunan kelapa sawit ternyata memberikan dampakpada peningkatan erosi. Erosi ini akan meningkatkan kekeruhan perairan dan pendangkalan khususnya di muara sungai (Sjakowi , 2007).

Selain Sungai Rokan, sungai lainnya yang banyak di huni oleh komunitas Melayu saat ini telah memasuki kondisi kritis yang disebabkan oleh banyaknya lahan disepanjang sungai yang dialihkan dari hutan yang fungsi ekologisnya sebagai penangkap air hujan menjadi lahan pertanian dan perkebunan. Akibatnya pada musim penghujan air Sungai Siak melimpah dan menimbulkan banjir besar di sepanjang daerah yang dilaluinya sehingga banyak menimbulkan kerugian masyarakat.

Kasus degradasi lingkungan lainnya di Melayuadalah kasus kehutanan. Berdasarkan data kehutanan, selama kurun waktu 12 tahun (1985-1997), terjadi pengurangan areal hutan seluas 864.809 ha (14,6 persen). Salah satu akibatdari deforestasi ini adalah hilangnya kawasan penyimpanan karbon (carbon sink) dan penyerapan karbon dalam bentuk fotosintesis tanaman yang pada akhirnya berpengaruh pada siklus karbon dan neraca karbon. Pembakaran hutan yang marak di Provinsi Riau dalan 10 tahun terakhir ini telah meningkatkan konsentrasi gas-gas $\mathrm{CO}$ dan $\mathrm{CO}_{2} \mathrm{di}$ udara yang selanjutnya meningkatkan efek rumah kaca dan pada akhimya mengakibatkan meningkatnya suhu bumi. Peningkatan suhu bumi ini selanjutnya berpengaruh terhadap perubahan iklim baik secara lokal maupun global (Sjakowi,2007).

Sejalan dengan perkembangan zaman, maka pada saat ini telah terjadi pergeseran kesadaran masyarakat Melayu terhadap nilainilai adat mereka. Pergesaran tersebut dapat dilihat dari peranan tokoh adat. Sebagai pemuka adat mereka seharusnya memberi contoh penerapan nilai-nilai adat secara aktual. Tetapi kini tidak lagi terlihat, bahkan yang terjadi adalah banyak hak-hak dilanggar yang tidak sesuai dengan nilai-nilai kearifan yang terkandung dalam adat Melayu (wawancara dengan Darmansyah, tokoh masyarakat Bagan Siapi-api, Rohil,tanggal 23 Agustus 2011).

Masyarakat Rohil terikat dengan sistem sosial budaya adat Melayu. Adat Melayu menjadi elemen normatif tertinggi untuk mengatur masyarakat Melayu. Adat Melayu memiliki nilai-nilai kearifan lingkungan dan seperangkat nilai filosofi, aktivitas dan material yang sangat potensial untuk dapat melestarikan lingkungan untuk menunjang pembangunan Kabupaten Melayuyang berkelanjutan.Disisi lain berdasarkan data diatas, degradasi lingkungan di Riau dari hari ke semakin krisis, sehingga perlu upaya yang serius untuk menanggulanginya dalam bentuk kebijakan formal yang memasukkan kearifan tradisional orang Melayu dalam kebijakan pemerintah dan partisipasi masyarakat dalam penyelamatan lingkungan hidup yang berkelanjutan.

\section{Paradigma Lingkungan: \\ Anthropocentrisme vs Ecocentrisme}

Dalam buku Etika Lingkungan (2010),Keraf menyatakan, krisis lingkungan berakar pada kesalahan perilaku manusia, dan kesalahan perilaku manusia berakar pada cara pandang manusia tentang dirinya, alam dan hubungan antara manusia dengan alam. Karena itulah, jika kita ingin memperbaiki keadaan, mengubah cara pandang yang antroposentris menjadi ekosentris adalah kebutuhan bersama.

Antroposentrisme ialah teori etika lingkungan yang memandang manusia sebagai pusat dari sistem alam semesta. 
Manusia dan kepentingannya dianggap yang paling menentukan dalam tatanan ekosistem dan dalam seluruh kebijakan yang diambil dalam kaitannya dengan alam, baik secara langsung ataupun tidak. Nilai tertinggi adalah manusia sekaligus kepentingannya (Keraf, 2010). Akibatnya, alam hanya diposisikan sebagai objek, instrumen, dan sarana bagi pemenuhan kebutuhan dan kepentingan manusia.

Antroposentrisme dilihat sebagai sebuah teori filsafat yang mengatakan bahwa nilai dan prinsip moral hanya berlaku bagi manusia, dan bahwa kebutuhan dankepentingan manusia mempunyai nilai paling tinggi dan paling penting. Bagi teori antroposentrisme, etika hanya berlaku bagi manusia. Maka, segala tuntutan mengenai perlunya kewajiban dan tanggung jawab moral manusia terhadap lingkungan hidup dianggap sebagai tuntutan yang berlebihan, tidak relevan dan tidak pada. tempatnya. Kalaupun tuntutan seperti itu masuk akal, itu hanya dalam pengertian tidak langsung, yaitu sebagai pemenuhan kewajiban dan tanggung jawab moral manusia terhadap sesama.

Maksudnya, kewajiban dan tanggung jawab moral manusia terhadap lingkungan hidup kalaupun ada, hanya semata-mata demi memenuhi kepentingan sesama manusia. Kewajiban dan tanggung jawab terhadap alam hanya merupakan perwujudan kewajiban dan tanggung jawab moral terhadap sesama manusia. Bukan merupakan perwujudan kewajiban dan tanggung jawab moral manusia terhadap alam itu sendiri(Keraf,2010).

Dalam pandangan antroposentris,alam dinilai sebagai alat bagi kepentingan manusia. Kalaupun manusia mempunyai sikap peduli terhadap alam, itu semata-mata dilakukan demi menjamin kebutuhan hidup manusia, bukan karena pertimbangan bahwa alam mempunyai nilai pada diri sendiri sehingga pantas untuk dilindungi. Sebaliknya, kalau alam itu sendiri tidak berguna bagi kepentingan manusia, alam akan diabaikan begitu saja.

Antroposentrisme juga disebut sebagai etika teleologic karena mendasarkan pertimbangan moral pada akibat dari tindakan tersebut bagi kepentingan manusia. Suatu kebijakan dan tindakan yang baik dalam kaitan dengan lingkungan hidup akan dinilai baik kalau mempunyai dampak yang menguntungkan bagi kepentingan manusia.Konservasi, misalnya, hanya dianggap serius sejauh itu bisa dibuktikan mempunyai dampak menguntungkan bagi kepentingan manusia, khususnya kepentingan ekonomis (Keraf, 2010).

Ekosentrisme merupakan teori etika lingkungan yang memusatkan diri pada seluruh komunitas lingkungan, baik yang hidup maupun tidak. la mendobrak cara pandang antroposentrisme yang hanya membatasi fokus keberlakuan etika pada komunitas manusia belaka. Antroposentrisme telah menjadikan manusia sebagai penguasa yang terus menerus mengeksploitasi alam. Menurut Redcliff (1990) komponen-komponen pertumbuhan dan paradigma lingkungan adalah sebagai berikut : 
Husni Thamrin, Zulfan Saam; ECO-Religio-Culture Suatu Alternatif Pengelolaan Lingkungan

Tabel 1

Paradigma Lingkungan Hidup

\begin{tabular}{|c|c|c|}
\hline No & Antroposentrisme & Ekosentrisme \\
\hline 1 & Dominan melawan alam & Harmonis dengan alam \\
\hline 2 & Lingkungan alam sebagi sumber & Nilai-nilai di alam /biosfer yang tidak memihak \\
\hline 3 & Tujuan material/pertumbuhan ekonomi & Tujuan non material/keberlanjutan lingkungan \\
\hline 4 & $\begin{array}{l}\text { Cadangan banyak/bahan pengganti } \\
\text { sempurna }\end{array}$ & Cadangan terbatas \\
\hline 5 & $\begin{array}{l}\text { Teknologi tinggi/penyelesaian ilmu } \\
\text { pengetahuan }\end{array}$ & Penyelesaian teknologi yang sesuai \\
\hline 6 & Konsumerisme & Kebutuhan dasar /daur ulang \\
\hline 7 & Tersentral /skala besar & Desentralisasi/skala kecil \\
\hline 8 & Otoriter/struktur memaksa & Partisipatoris/demokrastis. \\
\hline
\end{tabular}

Salah satu versi ekosentrisme ini adalah teori etika lingkungan yang kini populer dikenal dengan deep ecology. Sebagai sebuah istilah, deep ecology diperkenalkan pertama kali oleh Arne Naess, seorang filsuf Norwegia di tahun 1973. Naess (1973) akhirnya dikenal sebagai salah seorang tokoh utama gerakan deep ecology, yang tidak mengubah sama sekali hubungan antara manusia dengan manusia.

Ada dua hal yang sama sekali baru dalam deep ecology. Pertama, manusia dan kepentingannya bukan ukuran bagi segala sesuatu yang lain. Deep ecology memusatkan perhatian kepada seluruh spesies, termasuk spesies bukan manusia. la juga tidak memusatkan pada kepentingan jangka pendek, tetapi jangka panjang. Maka dari itu, prinsip moral yang dikembangkan deep ecology menyangkut seluruh kepentingan komunitas lingkungan. Kedua,deep ecology dirancang sebagai etika praktis. Artinya, prinsip-prinsip moral etika lingkungan harus diterjemahkan dalam aksi nyata dan konkret. Etika baru ini menyangkut suatu gerakan yang jauh lebih dalam dan komprehensif dari sekadar sesuatu yang amat instrumental dan ekspansionis. Deep ecology merupakan gerakan nyata yang didasarkan pada perubahan paradigma secara revolusioner, yaitu perubahan cara pandang, nilai dan perilaku atau gaya hidup.

Seperti dielaborasi oleh Sonny Keraf (2010) filsafat pokok deep ecology disebut Naess sebagai ecosophy, kombinasi antara "eco" yang berarti rumah tangga dan "sophy" yang berarti kearifan. Jadi, ecosophy bisa berarti kearifan mengatur hidup selaras dengan alam sebagai sebuah rumah tangga dalam arti luas. Ecosophy meliputi suatu pergeseran dari sekadar sebagai sebuah ilmu (science)menjadi sebuah kearifan (wisdom).

Pola hidup yang arif mengurus dan menjaga alam sebagai sebuah rumah tangga ini bersumber dari pemahaman dan kearifan bahwa segala sesuatu di alam semesta ini memiliki nilai pada dirinya sendiri, dan nilai ini jauh melampaui nilai yang dimiliki oleh dan untuk manusia. Karena itu, tidak hanya manusia yang memiliki nilai dan berbagai kepentingan yang harus dihargai, melainkan juga semua isi alam semesta ini. Kearifan ini menjelma menjadi pola dan gaya hidup tidak seenaknya menebangi hutan. Ini juga berarti memberi kesempatan kepada seluruh isi hutan untuk menikmati hidupnya.

Agama-agama yang dipeluk oleh masyarakat Indonesia, mulai dari Islam, Hindu, Kristen, Budha dan Konghuchu, juga terbukti mengajarkan pemeluknya untuk 
senantiasa menjaga dan memelihara alam sekitarnya. Bahkan menurutnya, sekarang ini beberapa organisasi keagamaan di Indonesia telah membentuk institusi yang bergerak dalam pengelolaan lingkungan hidup. (Keraf,2010).

"Semua kearifan lingkungan yang dimiliki tersebut, apabila kita rajut dan berdayakan akan sangat bermakna dalam upaya penyelamatan bumi". Sebagai kekuatan sosial, kearifan lokal tersebut akan menjadi kebutuhan utama dalam pengelolaan lingkungan hidup di Indonesia. Dalam penyelenggaraannya perlu ditunjang oleh kearifan-kearifan institusi dan konstitusi yang membumi dan selaras dengan sosial budaya masyarakat.

Menurut A. Sony Keraf (2010) sejak tahun 1980-an, agenda politik lingkungan hidup mulai dipusatkan pada paradigma pembangunan berkelanjutan. Mula pertama, istilah ini muncul dalam World Conservation Strategy dari International Union for the Consenvation of Nature (1980), lalu dipakai oleh Lester R. Brouwn dalam bukunya Building a Sustainable Society(1981). Istilah tersebut kemudian menjadi sangat populer melalui Laporan Brundtland, Our Common Future(1987). Akhirnya, pada tahun 1992, dalam Konferensi Tingkat Tinggi (KTT) Bumi di Rio de Janeiro, Brasil, paradigma pembangunan berkelanjutan diterima sebagai sebuah agenda politik pembangunan untuk semua negara di dunia. Hanya, hingga kini paradigma tersebut tidak banyak diimplementasikan, bahkan masih belum luas dipahami dan diketahui. Krisis ekologi masih saja terjadi, penghancuran dan pengrusakan lingkungan hidup terus berlangsung dan bahkan kian tidak terkendali. Artinya, paradigma pembangunan berkelanjutan belum mampu menjawab berbagai persoalan lingkungan hidup.
Sony Keraf (2010) mengatakan bahwa paradigma pembangunan berkelanjutan tersebut sebenarnya kembali menegaskan ideologi developmentalisme.Apa yang dicapai di KTT Bumi di Rio de Janeiro pada tahun 1992 yang lalu, tidak lain adalah sebuah kompromi yang mengunggulkan kembali pembangunan, dengan fokus utamanya berupa pertumbuhan ekonomi. Selain itu, menurut Salim (2010), krisis ekologi diakibatkan karena agenda pembangunan sumberdaya alam yang telah dijalankan saat ini, tidak melalui pendekatan paradigma pembaruan lingkungan hidup yang meletakkan prinsipnya pada nilai-nilai keberlanjutan kehidupan (keberlanjutan ekologi) maupun jaminan pada hak atas lingkungan hidup sebagai sumber-sumber kehidupan dan asasi rakyat.

Lingkungan hidup menyediakan kebutuhan-kebutuhan hidup manusia. Begitupun sebaliknya, kehidupan manusia sangat tergantung pada tersedianya sumberdaya alam yang memadai dalam lingkungan hidup.Persoalan lingkungan hidup mulai menjadi topik dunia ketika manusia mulai tersentak bahwa bumi sudah tidak ramah lagi dan mulai merasakan dampaknya yang semakin meluas akibat berbagai aktivitas manusia itu sendiri. Pertumbuhan penduduk dan perkembangan ilmu pengetahuan dan teknologi semakin meningkatkan aktivitas eksploitasi terhadap alam oleh manusia sehingga membuat alam tidak mampu lagi memperbaiki dirinya sendiri secara alami. Dengan kondisi seperti ini, lingkungan hidup perlu diatur dan dikelola dengan baik sehingga dapat memberikan manfaat yang optimal, mencukupi kebutuhan kehidupan generasi saat ini tanpa harus mengurangi kemampuannya untuk memenuhi kebutuhan kehidupan generasi yang akan datang. 
Husni Thamrin, Zulfan Saam; ECO-Religio-Culture Suatu Alternatif Pengelolaan Lingkungan

Krisis ekonomi semakin tak terpulihkan karena semua kekayaan negara dikuasai oleh segelintir elit politik dan modal. Kuasa-kuasa modal internasional telah menekan elit pemerintahan supaya memperoleh kemudahan-kemudahan akses dan penguasaan sumber-sumber kehidupan rakyat, aset negara (perusahaan-perusahaan milik negara), keringanan pajak, dan lain-lain. Perekonomian nasional telah tunduk dan takluk pada sistem kapitalisme global. Telah disahkan pula beberapa perundanganundangan yang memberi akses seluasluasnya bagi kepentingan modal dalam dan luar negeri atas sumber-sumber kehidupan rakyat.

Krisis sosial budaya terjadi karena proyek-proyek pembangunan dan perluasan investasi telah meluluhlantakkan basis sosiokultur rakyat di seluruh penjuru Nusantara. Konflik sosial antara rakyat dan negara, rakyat dan pemodal, juga antara rakyat dan rakyat semakin marak dan kompleks serta tak terselesaikan. Konflik-konflik sosial meningkat dengan dukungan kekuatan militeristik dari pihak yang lebih berkuasa dan kuat. Ambruknya sistem kebudayaan rakyat menjadikan rakyat tak mampu melakukan reproduksi sosial bagi keberlanjutan kehidupan generasi mendatang.

Krisis ekologi terjadi karena negara, pemodal, dan sistem pengetahuan 'modern' telah mereduksi alam menjadi onggokan komoditi yang bisa direkayasa dan dieksploitasi untuk memperoleh keuntungan ekonomi jangka pendek. Ekspansi sistem monokultur, eksploitasi hutan, industri keruk kekayaan tambang telah mengganggu dan menghancurkan fungsi-fungsi ekologi dan keseimbangan alam. Privatisasi kekayaan alam hanya diperuntukkan semata-mata untuk tujuan komersial, bahkan dengan alasan konservasi sekalipun telah menjauhkan akses dan kontrol rakyat pada sumber-sumber kehidupan (agraria-sumber daya alam). Pada gilirannya, berbagai bencana lingkungan, seperti kebakaran hutan dan lahan, banjir, kekeringan, pencemaran, dan krisis air telah menjadi bencana yang harus diderita oleh masyarakat adat dari tahun ke tahun.

\section{Eco- Religio Culture: Suatu Pendekatan}

Eco-religio-cultureadalah bentuk pandangan yang mengusahakan sedapat mungkin tercapainya keharmonisan lingkungannya dengan kebudayaan dan nilainilai agama. Dalam hal tertentu dalam ecorelgio culturebisa saja memasukkan komponen lingkungan alam, sosial dan ekonomi sebagai kesatuan yang tak terpisahkan dalam menjaga keharmonisan lingkungan (Northbourne, 1940). Dalam ecoreligio cultureselalu dijumpai unsur alam dan sosial dalam kombinasinya, sehingga dalam hal ini eco-relgio culture merupakan kajian sosio-ekologi-religius. Dalam istilah lain disebut juga integrated farming (atau integrated crop management, ICM) yang merupakan pola holistiksosio-budaya yang mengintegrasikan proses regulasi alami menjadi aktivitas masyarakat adat untuk mencapai peralihan maksimal dan untuk mempertahankan sosio-budaya. Sistemsistem yang terintegrasi didalamnya antara lain: multifunctional crop rotation, integrated nutrient management, minimum soil cultivation, integrated crop management, danecological infrastructure management. Eco-culturejuga disebut sebagai organic cuture atau metode sosial-budaya yang memperkecilmodernisasi dalam proses perubahan sosial.

Hal ini bertujuan untuk memproduksi hasil alam dengan nilai nutrisi tinggi dan mengimprovisasi fertilitas jangka panjang serta lingkungan yang berkelanjutan. Sistem ini 
memajukan dan meninggikan ekosistem, termasuk biodiversitas, siklus biologi dan aktivitas biologi di dalam tanah. Istilah organic farming sendiri ditemukan oleh Northbourne (1940) dari bukunya berjudul Look to the Land yang lahir dari konsepsinya tentang "budaya sebagai organisme", dimana dia memaparkan sebuah pendekatan holistik dan keseimbangan lingkungan dan sosio-budaya.

Prinsip utama sosio-culture adalah penggunaan input luar yang rendah yang berlawanan dengan penggunaan input luar yang tinggi. Berdasarkan prinsip tersebut, berkembang berbagai istilah seperti cyclic culture system, regeneratif culture, sustainable culture, organic culture, organic system, organic agriculture, biological agriculture, purely organic agriculture, dan eco-culture, yang merupakan kontras dari istilah-istilah conventionalculture, industrialized farm agriculture, dan industrialized farming system (Mugnisjah, 2001).Kultur organik merupakan hukum pengembalian (law of retum) yang berarti suatu sistem yang berusaha untuk mengembalikan semua jenis bahan organik ke dalam tanah baik dalam bentuk residu dan limbah pertanaman maupun ternak yang selanjutnya bertujuan memberi makanan pada tanaman (Sutanto, 2002).

Praktik eco- religio-culturetidak selalu menyalahkan lingkungan konvensional secara keseluruhan, melainkan menghubungkan dari konsep lingkungan konvensional menjadi sesuatu yang baik bagi alam mengacu pada konsep "kembali ke alam" yang berwawasan eco- religio-culture. Salah satu contohnya adalah pengelolaan ekofarming pada jenis pertanian kultivasi bergantian (shifting cultivation). Shifting cultivation atau pertanian slash and burm (potong dan bakar) dikenal juga sebagai ladang-hutan bergantian. Pengelolaan lingkungan dalam hal ini mengacu pada masalah masa tandus (fallow) dan masa tanam secara bergantian untuk keberlanjutan lingkungan.

Hingga saat ini, shifting cultivation sendiri belum cukup dimengerti, selalu disebut primitif, boros, ilegal, tanpa mengambil pertimbangan variabel lokal seperti kerapatan populasi, areal lahan yang tersedia, iklim, tanah, atau kearifan lokal pertanian. Meskipun pengertian pertanian bergantian (shifting cultivation) masih dalam perdebatan namun banyak pakar menyetujui bahwa pada istilah tersebut terdapat komponen arti yaitu berbagai macam aplikasi bertani yang memiliki masa tandus dalam arti untuk mempertahankan produktivitas ecologis.

Sementara itu dua alasan utama dilakukannya penandusan (fallow) adalah untuk mengeliminasi keberadaan gulma dan membangun fertilitas ekosistem. Gulma tentu saja dianggap mengganggu bagi lahan pertanian dalam hal kompetisi nutrisi pada tanah dimana gulma memiliki ketahanan hidup yang tinggi dan pertumbuhan yang super cepat. Hal ini tentu saja menjadi kompetitor besar bagi komoditas pertanian. Beberapa studi memperlihatkan apakah peningkatan tekanan gulma berkorelasi dengan reduksi panen.

Fertilitas ekosistem berhubungan juga dengan pembersihan ladang dari gulma pada masa tandus, menurut Clarke (1976) dan Dove (1985) dari berbagai studi mengindikasikan bahwa hutan sekunder yang muda berkembang menuju hutan yang matang karena kemudahan dalam pembersihan (easyclearing). Hal ini karena pengaruh kuat masa tandus terhadap kondisi tanah pada masa berladang setelah melalui masa tandus.

Eco-religio-culture memiliki keuntungan baik dari segi lingkungan maupun sosialekonomi-ekologis karena sistem ini memang mengintegrasikan ketiganya. Keuntungan lingkungan jelas didapat diantaranya,hutan, 
Husni Thamrin, Zulfan Saam; ECO-Religio-Culture Suatu Alternatif Pengelolaan Lingkungan

tanah, nilai tradisonal konservasi air, siklus daur ulang hara pada tanah, biodiversitas yang tinggi, dan tentu saja fertilitas ekosistem sehingga didapat lingkungan berkelanjutan (Bronfenbrenner,1979).Revitalisasi ekonomi didapat dari optimalisasi produksi pertanian melalui berbagai cara pertanian seperti diversifikasi komoditas dalam satu petak (multiple cropping), dapat juga dengan lahan kecil dan sumber daya pekerja minimum dengan cara permaculture (permanent agriculture) atau implementasi pertanian skala kecil bahkan mikro yang diintegrasikan dengan habitat manusia dan diserahkan pada pola ekosistem alami.

Pada sistem ekonomi, eco-religioculturesebetulnya dapat masuk pada sistem capital employed maupun subsistence tergantung pola hubungan manusialingkungan yang diarahkan pada kesejahteraan manusia. Bila mendefinisikan kesejahteraan dengan penghasilan tinggi maka hasil surplus eco-culturedapat dipasarkan secara global (capital) maupun lokal (subsisten) dengan produk yang unggul dari segi alamiah. Bila kesejahteraan dapat diterjemahkan pada terpenuhinya kebutuhan manusia maka hasil panen dapat mencukupi konsumsi pangan keluarga bahkan saling berbagi surplus panen, tentu saja hal inihanya ada pada sistem subsistem.

Hal ini bertujuan untuk memproduksi hasil tani dengan nilai nutrisi tinggi dan mengimprovisasi fertilitas jangka panjang serta tanah pertanian yang berkelanjutan. Sistem ini memajukan dan meninggikan ekosistem, termasuk biodiversitas, siklus biologi dan aktivitas biologi lingkungan. Pengunaan konsep eco-religio- culture dalam keberlanjutan lingkungan masyarakat adalah sangat baik, sebab secara kultur religius mereka secara alamiah telah lama menjadi harmonisasi alam dengan manusia. Untuk menerapkan konsep ini harus didukung oleh kebijakan yang berwawasan eco-religio culture.

\section{Metode}

Penelitian ini menggunakan metode kualitatif grounded research, yang bertujuan untuk memahami keberadaan yang saling berhubungan antara berbagai gejala eksternal dan internal dalam kehidupan masyarakat adat di Kabupaten Rokan Hilir. Dalam kaitan antropologi lingkungan, studi ini menggunakan pendekatan struktural. Dalam pendekatan ini lingkungan dilihat dalam pengertian hubungan formal, yang mengungkap hubungan lingkungan hidup yang nyata antara individu dan kelompok. Pendekatan ini lebih jauh menekankan pada model-model pendeskripsian realitas lingkungan sebagai keadaan yang koheren, menekankan keseimbangan, sedangkan dalam realitasnya tidak memiliki karakteristik koherensi yang menyeluruh.

Realitas lingkungan memiliki kontradiksi yang menampilkan berbagai variasi dan modifikasi atas strukturnya. Dalam pada itu dipertimbangkan pula pendekatan dinamik yang bermaksud menjelaskan dinamik dan struktur dalam metode dan sistem yang membentuknya, yakni untuk melihat, kontradiksi, ketegangan, dan gerak inheren, dalam masyarakat (Ballandier, 1996:19-21). Kesemua pendekatan yang digunakan diatas dilihat dalam konteks pendekatan (paradigma) kualitatif. Pendekatan kualitatif dicirikan oleh tujuan penelitian yang berupaya untuk memahami gejala-gejala yang sedemikian rupa sehingga tidak memerlukan kuantifikasi dimana gejala-gejala tersebut tidak memungkinkan diukur secara tepat (Garna, 1999:32 dan Moleong, 1989: 2-3).

Langkah operasional di lapangan dilakukan secara sistematik untuk menjawab pertanyaan dasar penelitian yang telah dikemukakan sebagai masalah penelitian. 
Diharapkan melalui penelitian ini akan melahirkan pemikiran hipotetik.

Deskripsi dan ungkapan tentang fenomena empirik sebagai realitas obyektif masyarakat, akan lebih ditekankan pada metode deskriptif. Penelitian deskriptif bertujuan untuk menggambarkan dan memahami pola eco-religio-culturesuatu masyarakat dalam konteks keutuhan sebagai kesatuan yang bulat. Penelitian deskriptif dalam konteks eco-religio-culture dengan pendekatan struktural dan dinamik, menghasilkan konsep-konsep ilmiah sekaligus berfungsi mengadakan klasifikasi mengenai gejala sosial yang dipersoalkan.

Penelitian ini secara keseluruhan bersifat kualitatif menggunakan azas fenomenologi. Menurut Garna (1999:34) sifat yang kualitatif itu mengacu pada segi empirik yaitu kehidupan nyata manusia termasuk segala apa yang berada di belakang pola sikap dan tindakannya sebagai manusia biososial.Asas fenomenologi, yang dimaksud disini menekankan aspek-aspek subyektif dari perilaku manusia. Peneliti berusaha untuk masuk kedalam dunia konseptual pada subyek yang ditelitinya, sehingga peneliti memahami apa, bagaimana dan sejauhmana pengertian itu akan dikembangkan di sekitar peristiwa dan kehidupan sehari-hari.

Menurut Maxwell (1996) dalam Gunawan dan Abdullah(1998) studi kualitatif dilakukan untuk:

1) Mengungkapkan atau memahami "meaning" (makna yang mencakup kognisi affect, intentions, atau hal-hal lain sebagai perspektif partisipan.

2) Memahami konteks tertentu yang partisipasinya ialah melakukan berbagai tindakan dan memahami pengaruh dari konteks tertentu terhadap tindakan mereka (partisipan).

3) Mengidentifikasi gejala dan pengaruh yang tidak terantisipasi sebelumnya dan membuat teori-teori baru yang akan mengembangkan teori-teori sebelumnya.

4) Memahami terjadinya berbagai peristiwa dan tindakan.

5) Membangun penjelasan kausal.

Pendekatan kualitatif dapat digunakan untuk menggambarkan pola relasi ecoculturedalam masyarakat, yang sulit dilakukan dengan pendekatan kuantitatif. Lebih dari itu Patton (1990) mengemukakan metoda kualitatif memungkinkan peneliti untuk melakukan studi tentang issue tertentu secara mendalam dan terinci.

Pendekatan grounded research menitik beratkan pada ciri-ciri sebagai berikut:

1. Mengeksplorasi latar penelitian tanpa melakukan intervensi pada latar penelitian.

2. Mengungkapkan makna deskripsi rinci tentang situasi, orang atau masyarakat, kejadian, interaksi dan perilaku yang dapat diamati.

3. Data kualitatif berbentuk deskripsi rinci tentang ungkapan filosopi, dalam petuah, petatah petitih, pantun ,syair, hikayat, situasi, orang atau masyarakat, kejadian, interaksi dan perilaku yang dapat diamati.

4. Deskripsi rinci menyangkut pengamalan, sikap, keyakinan individu atau masyarakat atau seluruh isi dokumen, rekaman dan kasus.

5. Data kualitatif diperoleh dari dunia empirik dalam bentuk detailed description atau uraian terbuka yang bebas dari segala usaha menyesuaikannya dengan program kegiatan dan pengalaman manusia dalam bentuk standar kategori yang ditentukan terlebih dahulu seperti pilihan jawaban yang terdapat dalam angket atau pedoman observasi. 
Husni Thamrin, Zulfan Saam; ECO-Religio-Culture Suatu Alternatif Pengelolaan Lingkungan

6. Menggunakan pendekatan holistik atau menyeluruh, induktif, bergerak dari satu fakta ke fakta lain sampai ditemukan gambaran umum tentang sesuatu yang diteliti.

7. Pengumpulan data menggunakan kerangka konseptual dengan tujuan membatasi fokus penelitian.

\section{Lokasi dan Obyek Penelitian}

Penelitian ini dilakukan di Kabupaten Rokan Hilir, Provinsi Riau. Penelitian mengenai Revitalisasi Kearifan Lokal dalam kontekshuman ekologi. Data diperoleh dari informan Datuk-Datuk, Penghulu Adat, dan Tokoh Masyarakat. Penelitian terhadap pelestarian lingkungan hidup yang berkaitan dengan kearifan lokal di Kabupaten Rokan Hilir, terutama dominan di Kecamatan Kubu, Bangko dan Tanah Puth. Ketiga kecamatan ini merupakan kecamatan induk di Melayuyang telah ada dan diakui sejak zaman kerajaan Siak Sri Indrapura (1746-1942). Pada ketiga kecamatan ini yang dulunya adalah merupakan kenegerian yang dipimpin langsung oleh Datuk- Datuk.

Kecamatan Kubu, Bangko dan Tanah Putih dijadikanwilayah penelitian karena di wilayah ini masih relatif ketat mempunyai tradisi kearifan lokal dalam melestarikan kearifan lingkungan yang berwujud dalam petatah-petitih, petuah dan nasihat dalam tradisi pemeliharaan tanah, hutan dan laut. Dalam tradisi adat di Rokan Hilir,Sungai Rokan, Kubu, Bangko, dan sungai di kawasan iniyang dijadikan obyek penelitian yang berkaitan dengan kearifan lokal sehingga kawasan habitat sungai, terutama ikan-ikan dapat terpelihara dari kemusnahan. Kajian terhadap hutan tanah adat serta flora dan fauna,juga dilakukan, sehingga keberlanjutan lingkungan dapat dipertahankan.

Saat ini (2015) ketiga kecamatan yang merupakan inti kebudayaan Melayuini telah dimekarkan perluasan admistrasinya menjadi 14 (empat belas) kecamatan yang dijadikan lokasi penelitian

\section{Data yang Diperlukan}

Data pokok yang dikumpulkan dalam penelitian ini terpusat pada fenomenafenomena yang berkaitan langsung khususnya dengan tanah adat, yang berkaitan dengan aspek kehidupan sosial, lingkungan dan ekonomi dengan kontek eco-culture. Data pokok yang diperlukan tersebut dipilih dan dibatasi berdasarkan relevansi dengan pertanyaan dasar dalam rencana penelitian, yang keseluruhannya ditempatkan dalam rangka analisis teori antropologi lingkungan.

Tabel 3.1

Lokasi Penelitian

\begin{tabular}{|c|l|l|}
\hline No & \multicolumn{1}{|c|}{ Kecamatan } & \multicolumn{1}{c|}{ Ibukota } \\
\hline 1 & Tanah Putih & Sedinginan \\
\hline 2 & Pujud & Pujud \\
\hline 3 & Tanah Putih Tanjung Melawan & Melayu Besar \\
\hline 4 & Rantau Kopar & Rantau Kopar \\
\hline 5 & Bagan Sinembah & Bagan Batu \\
\hline
\end{tabular}




\begin{tabular}{|r|l|l|}
\hline No & \multicolumn{1}{|c|}{ Kecamatan } & \multicolumn{1}{c|}{ lbukota } \\
\hline 6 & Simpang Kanan & Simpang Kanan \\
\hline 7 & Kubu & Teluk Merbau \\
\hline 8 & Pasir Limau kapas & Panipahan \\
\hline 9 & Bangko & Bagan Siapiapi \\
\hline 10 & Sinaboi & Sinaboi \\
\hline 11 & Batu Hampar & Bantayan \\
\hline 12 & Rimba Melintang & Rimba Melintang \\
\hline 13 & Bangko Pusako & Bangko kanan \\
\hline 14 & Pekaitan & Pedamaran \\
\hline
\end{tabular}

Sumber : BPS, MelayuDalam Angka 2014

Dalam pada itu data tentang kondisi lingkungan hidup dan unsur-unsur kebudayaan lainnya yang bersifat umum tetap dikumpulkan selama penelitian lapangan dan penelitian kepustakaan berlangsung. Hal ini dilakukan untuk mendapatkan hasil analisis data pokok kedalam kesatuan kebudayaan orang Melayu secara holistik.

\section{Teknik Pengumpulan Data}

Pengumpulan data primer di lapangan dilakukan dengan menggunakan teknik pengamatan keikutsertaan (participantobservation) disamping wawancara mendalam (in-depth interview) dan wawan-cara biasa.

Penelitian ini dilakukan secara partisipasi kedalam kehidupan sehari-hari orang Melayu Rokan Hilir. Penulis memilih Kecamatan Kubu sebagai tempat tinggal dan sekaligus pos kegiatan, dan dilakukan secara periodik perjalanan lapangan (field trip) masuk kedalam lingkungan sehari-hari orang Melayu selama antara satu sampai tiga minggu. Dalam pada itu setelah mendapatkan data dari perjalanan tersebut, kesibukan terpusat pada desa penelitian ini; menyempurnakan catatan harian, melakukan klasifikasi lapangan, menterjemahkan dan menulis transkrip rekaman wawancara.

Pengamatan dilakukan secara spontan dan langsung, dengan bantuan kamera foto dan slide, baik terhadap aspek lingkungan hidup sekitar maupun berbagai fenomena kehidupan masyarakat Rokan Hilir.

Berdasarkan karakteristik masyarakat yang ada maka yang menjadi informan dalam penelitian ini berjumlah 57 orang. Untuk melihat kebenaran data dalam penelitian ini dilakukan cross check data diantara informaninforman yang telah ditentukan di lapangan. Untuk memperjelas perincian informan penelitian ini dapat dilihat pada tabel berikut. 
Husni Thamrin, Zulfan Saam; ECO-Religio-Culture Suatu Alternatif Pengelolaan Lingkungan

Tabel .2

Informan Kunci Penelitian

\begin{tabular}{|c|l|c|c|l|}
\hline No. & \multicolumn{1}{|c|}{ Status Sosial } & Jumlah & Usia & Tingkat Pendidikan \\
\hline 1. & Datuk-Adat & 6 & $55-80$ & SLTA-PT \\
2. & Tongkat & 3 & $60-75$ & SD-SLTA \\
3. & Dukun & 3 & $55-75$ & SD \\
4. & Khalifah & 3 & $60-70$ & SD-SLTA \\
5. & Penghulu & 3 & $60-80$ & SLTA-PT \\
6. & Tukang Koba & 6 & $55-80$ & SD-SLTA) \\
7. & Datuk Bendaharo & 7 & $40-75$ & SLTA-PT \\
8. & Masyarakat Biasa & 4 & $30-45$ & SLTA-PT \\
9. & Tokoh Masyarakat & 10 & 73 & SLTA-PT \\
10. & Lembaga Adat Rohil & 5 & 51 & SLTA-PT \\
\multicolumn{2}{|c|}{ Total } & 50 & & \\
\hline
\end{tabular}

Sumber: Hasil observasi dan wawancara (2013-2014)

Wawancara mendalam dilakukan secara intensif terhadap sejumlah informan kunci. Wawancara dilakukan dalam bahasa daerah setempat yaitu bahasa Melayu Melayuatau informan lain yang telah dapat berkomunikasi dengan bahasa Indonesia.

\section{Teknik Analisis Data}

Kegiatan analisis data dimulai dari klasifikasi, kategorisasi, dan interpretasi, sampai pada pembahasan. Pengolahan data atau analisis deskriptif (descriptive analysis) mengandung pengertian sebagai usaha untuk menyederhanakan dan sekaligus menjelaskan bagian dari keseluruhan data melalui langkah-langkah klasifikasi dan kategorisasi sehingga tersusun suatu rangkaian deskripsi yang sistematik dan akurat.

Proses pengklasifikasian dan pengkategorisasian data dilakukan sejak berada di lapangan, bersamaan dengan proses pengumpulan data dan dilanjutkan secara lebih terperinci dan sistimatis setelah keseluruhan data terkumpul. Klasifikasi dan kategorisasi data dilakukan secara bagian perbagian, akan tetapi tetap mempertahankan posisi kebudayaan Melayu Melayusebagai satu kesatuan yang utuh. Dalam proses kategorisasi data tersebut terkandung usaha interpretasi kualitatif yang dilakukan secara induktif berdasarkan pada pendekatan emik (emic approach). Dalam kaitan ini langkah pendekatan etik ditempatkan dalam kerangka teori antropologi lingkungan untuk melihat arti penting tanah adat sebagai sumber kehidupan dan pelestarian lingkungan.

Kategorisasi data mengandung interpretasi kualitatif tersebut diikuti dengan langkah-langkah pembahasan melalui metode komperatif. Dalam hal ini berupa perbandingan fungsional antar komponen atau unsur lingkungan suatu kebudayaan. Gambaran yang terwujud mencerminkan posisi orang Melayu Melayu dalam kontek eco-culture dalam mempertahankan pelestarian lingkungan hidup yang berbasiskan pada tanah adat.

Dalam penelitian ini data yang dianalisis terdiri dari data primer dan sekunder. Analisis fokus penelitian berkaitan dengan identifikasi masalah dan tujuan penelitian yang dibagi menjadi fokus dan sub fokus penelitian sebagai berikut : 
Tabel 3

Fokus dan Sub Fokus Analisis Penelitian

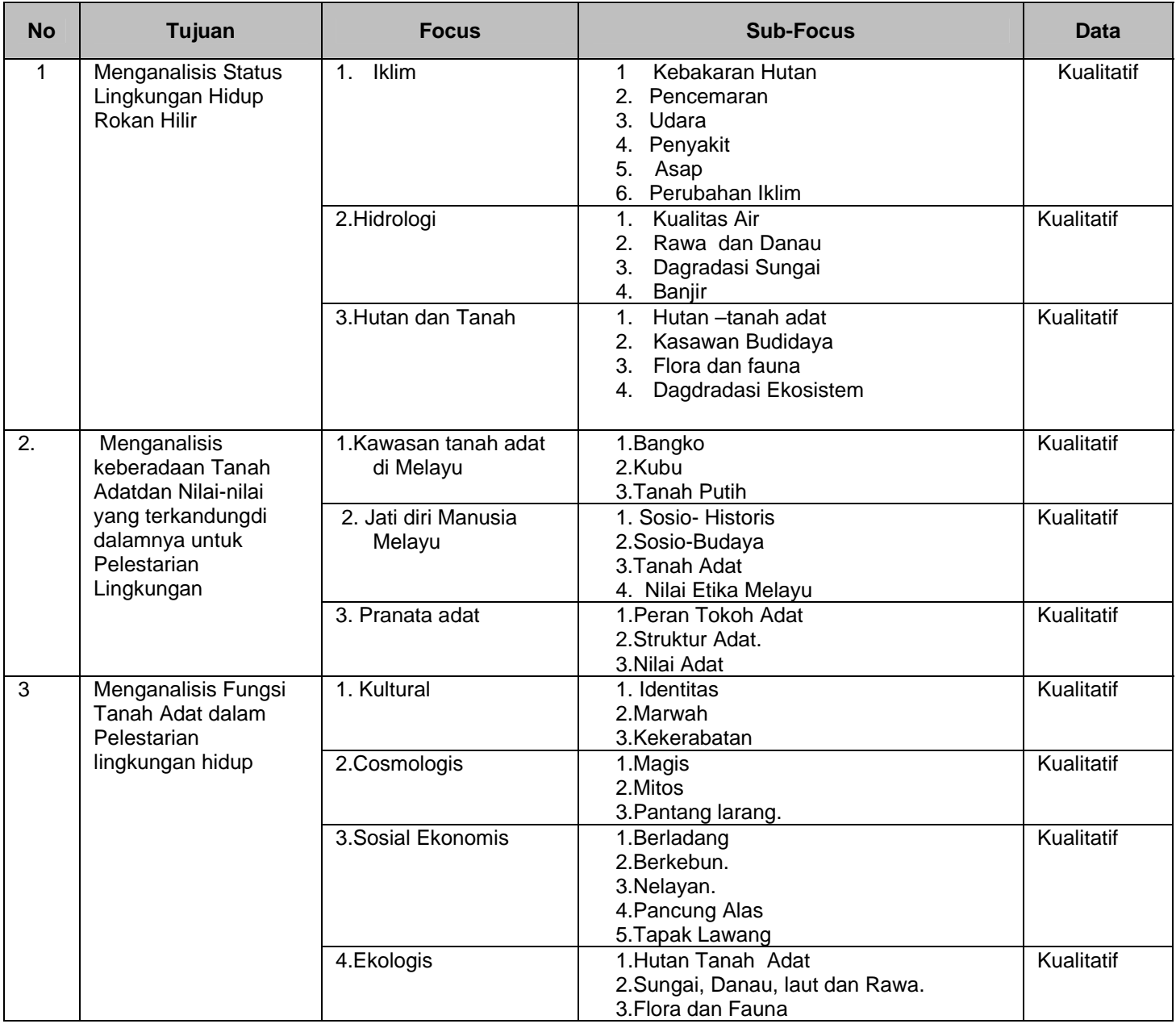

rencana penelitian, yang keseluruhannya ditempatkan dalam rangka analisis teori antropologi lingkungan.

Dalam pada itu data tentang kondisi lingkungan hidup dan unsur-unsur kebudayaan lainnya yang bersifat umum tetap dikumpulkan selama penelitian lapangan dan penelitian kepustakaan berlangsung. Hal ini dilakukan untuk mendapatkan hasil analisis data pokok kedalam kesatuan kebudayaan orang Melayu secara holistik.

\section{Teknik Pengumpulan Data}

Pengumpulan data primer di lapangan dilakukan dengan menggunakan teknik pengamatan keikutsertaan (participantobservation) disamping wawancara mendalam (in-depth interview) dan wawancara biasa.

Penelitian ini dilakukan secara partisipasi kedalam kehidupan sehari-hari orang Melayu Rokan Hilir. Penulis memilih Kecamatan Kubu sebagai tempat tinggal dan sekaligus pos kegiatan, dan dilakukan secara 
Husni Thamrin, Zulfan Saam; ECO-Religio-Culture Suatu Alternatif Pengelolaan Lingkungan

periodik perjalanan lapangan (field trip) masuk kedalam lingkungan sehari-hari orang Melayu selama antara satu sampai tiga minggu. Dalam pada itu setelah mendapatkan data dari perjalanan tersebut, kesibukan terpusat pada desa penelitian ini; menyempurnakan catatan harian, melakukan klasifikasi lapangan, menterjemahkan dan menulis transkrip rekaman wawancara.

Pengamatan dilakukan secara spontan dan langsung, dengan bantuan kamera foto dan slide, baik terhadap aspek lingkungan hidup sekitar maupun berbagai fenomena kehidupan masyarakat Rokan Hilir.

Berdasarkan karakteristik masyarakat yang ada maka yang menjadi informan dalam penelitian ini berjumlah 57 orang. Untuk melihat kebenaran data dalam penelitian ini dilakukan cross check data diantara informaninforman yang telah ditentukan di lapangan. Untuk memperjelas perincian informan penelitian ini dapat dilihat pada tabel berikut.

Tabel .2

Informan Kunci Penelitian

\begin{tabular}{|c|l|c|c|l|}
\hline No. & \multicolumn{1}{|c|}{ Status Sosial } & Jumlah & Usia & \multicolumn{1}{|c|}{ Tingkat Pendidikan } \\
\hline 1. & Datuk-Adat & 6 & $55-80$ & SLTA-PT \\
2. & Tongkat & 3 & $60-75$ & SD-SLTA \\
3. & Dukun & 3 & $55-75$ & SD \\
4. & Khalifah & 3 & $60-70$ & SD-SLTA \\
5. & Penghulu & 3 & $60-80$ & SLTA-PT \\
6. & Tukang Koba & 6 & $55-80$ & SD-SLTA) \\
7. & Datuk Bendaharo & 7 & $40-75$ & SLTA-PT \\
8. & Masyarakat Biasa & 4 & $30-45$ & SLTA-PT \\
9. & Tokoh Masyarakat & 10 & 73 & SLTA-PT \\
10. & Lembaga Adat Rohil & 5 & 51 & SLTA-PT \\
\hline \multicolumn{2}{|c|}{ Total } & 50 & & \\
\hline
\end{tabular}

Sumber: Hasil observasi dan wawancara (2013-2014)

Wawancara mendalam dilakukan secara intensif terhadap sejumlah informan kunci. Wawancara dilakukan dalam bahasa daerah setempat yaitu bahasa Melayu Melayuatau informan lain yang telah dapat berkomunikasi dengan bahasa Indonesia.

\section{Teknik Analisis Data}

Kegiatan analisis data dimulai dari klasifikasi, kategorisasi, dan interpretasi, sampai pada pembahasan. Pengolahan data atau analisis deskriptif (descriptive analysis) mengandung pengertian sebagai usaha untuk menyederhanakan dan sekaligus menjelaskan bagian dari keseluruhan data melalui langkah-langkah klasifikasi dan kategorisasi sehingga tersusun suatu rangkaian deskripsi yang sistematik dan akurat.

Proses pengklasifikasian dan pengkategorisasian data dilakukan sejak berada di lapangan, bersamaan dengan proses pengumpulan data dan dilanjutkan secara lebih terperinci dan sistimatis setelah keseluruhan data terkumpul. Klasifikasi dan kategorisasi data dilakukan secara bagian perbagian, akan tetapi tetap mempertahankan posisi kebudayaan Melayu Melayusebagai satu kesatuan yang utuh. Dalam proses kategorisasi data tersebut terkandung usaha interpretasi kualitatif yang dilakukan secara induktif berdasarkan pada pendekatan emik 
(emic approach). Dalam kaitan ini langkah pendekatan etik ditempatkan dalam kerangka teori antropologi lingkungan untuk melihat arti penting tanah adat sebagai sumber kehidupan dan pelestarian lingkungan.

Kategorisasi data mengandung interpretasi kualitatif tersebut diikuti dengan langkah-langkah pembahasan melalui metode komperatif. Dalam hal ini berupa perbandingan fungsional antar komponen atau unsur lingkungan suatu kebudayaan.
Gambaran yang terwujud mencerminkan posisi orang Melayu Melayudalam kontek eco-culture dalam mempertahankan pelestarian lingkungan hidup yang berbasiskan pada tanah adat.

Dalam penelitian ini data yang dianalisis terdiri dari data primer dan sekunder. Analisis fokus penelitian berkaitan dengan identifikasi masalah dan tujuan penelitian yang dibagi menjadi fokus dan sub fokus penelitian sebagai berikut :

Tabel 3

Fokus dan Sub Fokus Analisis Penelitian

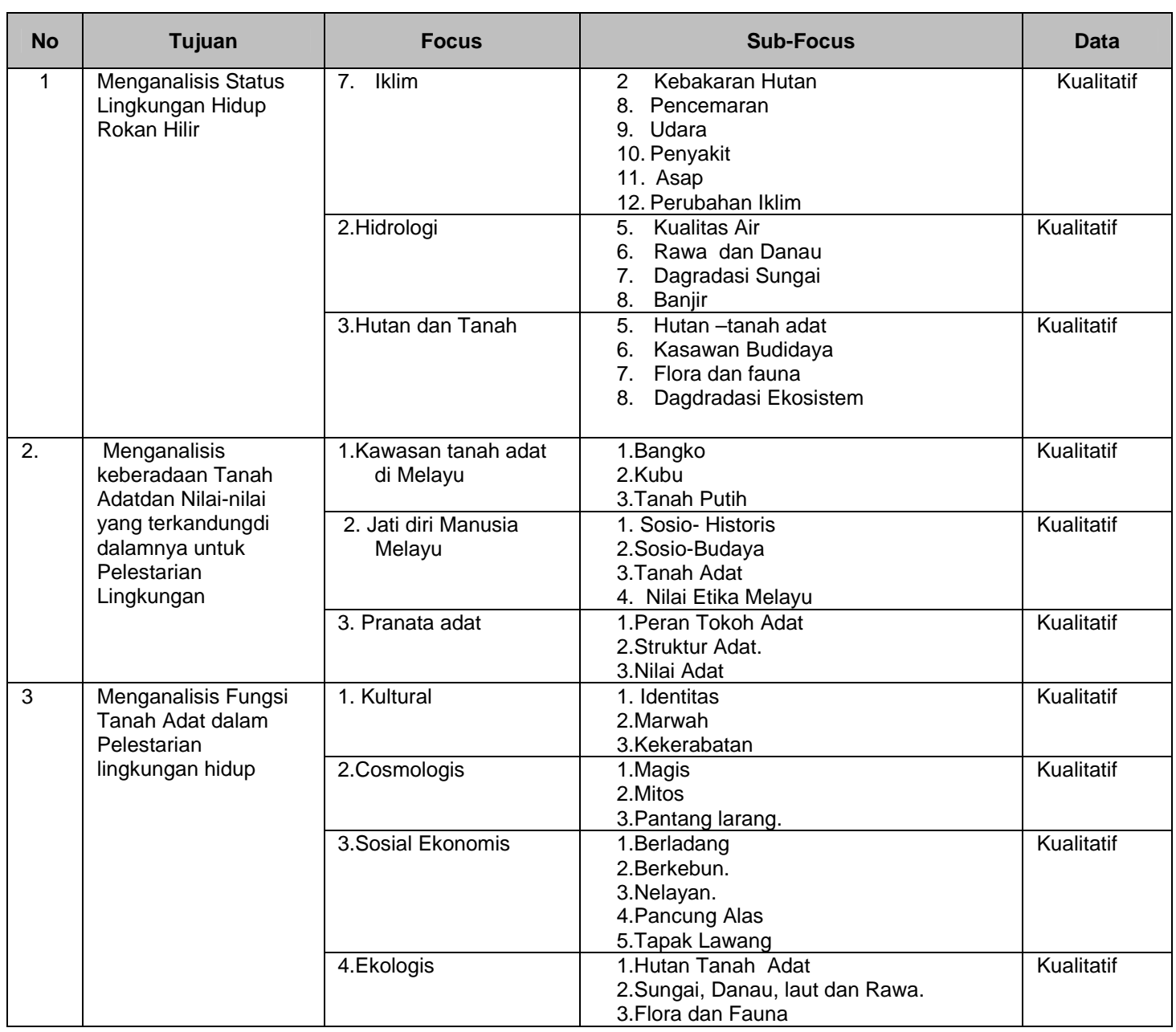


Husni Thamrin, Zulfan Saam; ECO-Religio-Culture Suatu Alternatif Pengelolaan Lingkungan

\section{Eco-Religio-Culture dalam Pelestarian Lingkungan}

Dalam penuturan informan Arsyad (73 tahun, tokoh adat di Bangko) mengatakan bahwa kehidupan mereka sangat bergantung kepada alam. Alam menjadi sumber nafkah dan juga menjadi sumber unsur-unsur budayanya. Dalam ungkapan dikatakan:

Kalau tidak ada laut,hampalah perut, Bila tak ada hutan, binasalah badan. Kalau binasa hutan yang lebat,rusak lembaga hilanglah adat.

Ungkapan-ungkapan di atas secara jelas menunjukkan bersebatinya hubungan antara orang Melayu dengan alam sekitarnya. Kebenaran isi ungkapan ini secara jelas dapat dilihat dalam kehidupan manusia Melayu sehari-hari. Secara tradisional, mereka secara turun-temurun hidup dari hasil laut dan hasil hutan atau mengolah tanah. Secara turuntemurun pula mereka memanfaatkan hasil hutan untuk berbagai keperluan, membuat bangunan, membuat alat dan kelengkapan rumah tangga, alat dan kelengkapan nelayan, alat berburu, alat bertani, dan sebagainya, termasuk untuk ramuan obat tradisionalnya. Orang Melayu tradisional yang hakikatnya hidup sebagai nelayan dan petani sangat bersebati dengan alam lingkungannya. Alam bukan saja dijadikan alat mencari nafkah, tetapi juga berkaitan dengan kebudayaan dan kepercayaannya ( Effendi, 2004: 662).

Menyadari eratnya kaitan antara kehidupan manusia dengan alam, menyebabkan orang Melayu berupaya memelihara serta menjaga kelestarian dan keseimbangan alam lingkungannya. Dalam adat istiadat ditetapkan "pantang larang" yang berkaitan dengan pemeliharaan serta pemanfaatan alam, mulai dari hutan, tanah, laut dan selat, tokong dan pulau, suak dan sungai, tasik dan danau, sampai kepada kawasan yang menjadi kampung halaman, dusun, ladang, kebun dan sebagainya.

Dalam penuturan informan Samuel (78 tahun, tokoh adat di Kubu) sekaligus sebagai narasumber beliau mengatakan sangat menyadari pentingnya pemeliharaan dan pemanfaatan lingkungan hidup sekitar secara seimbang. Ketentuan adat yang mereka pakai memiliki sanksi hukum yang berat terhadap perusak alam. Sebab, perusak alam bukan saja merusak sumber ekonomi, tetapi juga membinasakan sumber berbagai kegiatan budaya, pengobatan, dan lain-lain yang amat diperlukan oleh masayarakat.

Dalam adat Melayu dikenal beberapa pembagian alam, terutama pembagian hutan tanah. Ada alam yang boleh dimiliki pribadi, ada yang diperuntukkan bagi satu suku dan kaum, ada juga yang diperuntukkan bagi kerajaan, negeri, masyarakat luas dan sebagainya. Hutan-tanah ditentukan pula pemanfatannya menurut adat, ada pemanfaatan untuk kepentingan pribadi dan ada pemanfaatan untuk kepentingan bersama. Hal ini tercermin dari hutan yang dilindungi yang disebut "rimba larangan", "rimba kepungan", atau "kepungan sialang", dan lain sebagainya.

Dari sisi lain, masyarakat Melayu mengenal pula hutan tanah yang menjadi milik persukuan atau kaum masyarakat tertentu yang lazim disebut'tanah wilayat" (tanah adat) dan sejenisnya yang secara umum disebut "tanah adat". Pada masa dulu, pemilikan, penguasaan, dan pemanfaatan hutan tanah yang tergolong tanah adat dikukuhkan oleh raja melalui surat keputusan.

Dalam penuturan informan kunci Alju( 36 tahun, Datuk Penghulu, Rantau Bais, Tanah Putih) setelah Indonesia merdeka, hampir seluruh hak atas tanah adat tidak lagi diakui, sehingga pemilikan, pemanfaatan, dan 
penguasaannya tidak lagi dapat diatur oleh adat. Akibatnya, terjadi perusakan hutan dimana-mana. Masyarakat sekitar tempatan yang secara turun-temurun merasa menguasai dan memiliki hutan tanah itu tidak dapat berbuat apa-apa, karena mereka tidak lagi diakui sebagai pemiliknya. Hal ini menyebabkan banyak terjadinya sengketa tanah yang timbul setelah adanya bangunan atau perkebunan di kawasan itu, ketika hutan tanah itu diperjualbelikan atau dipindahkan hak kepemilikan, penguasaan, dan pemanfaatan ke pihak lain.

Petuah amanah Melayu yang amat memperhatikan eco-religio-culture dalam kelestarian dan keseimbangan alam lingkungan banyak berisi tunjuk ajar pantang larang dan acuan masyarakat agar tidak sampai merusak alamnya, antara lain (Effendi, 2004).

'tanda orang memegang adat, alam dijaga, petuah diingat,tanda orang memegang amanah, pantang merusak hutan dan tanah. Adat hidup memegang amanah, tahu menjaga hutan dan tanah, tahu menjaga bukit dan lembah, berladang tidak merusak tanah, berkebun tidak merusak rimba."

Tennas Efendi dalam petuah amanahnya secara jelas menunjukkan manfaat pelestarian dan menunjukkan pula keburukan merusak alam. Dalam ungkapan dikatakan: (Effendi, 2004).

"Kalau terpelihara alam sekitar, manfaatnya banyak faedahnya besar. di situ dapat tempat bersandar, di situ dapat tempat berlegar,di situ dapat membuang lapar, di situ adat dapat didengar, di situ kecil menjadi besar, di situ sempit menjadi lebar,tanda orang tak mensyukuri nikmat, memanfaatkan alam tak tahu hemat, tanda orang tak tahu diri, merusak alam setiap hari".

Bait-bait petuah dalam ungkapan di atas secara nyata menunjukkan betapa buruknya pandangan orang Melayu terhadap siapa saja yang merusak alam lingkungan, mencemarkan kelestarian dan tanpa memikirkan akibatnya bagi kehidupan masa kini dan anak cucunya di kemudian hari.

Menurut Andrew P. Vayda (1969) dua cara utama dalam menghubungkan perilaku kebudayaan dan fenomena lingkungan dapat dibedakan: (1) menunjukkan bahwa elemenelemen perilaku kebudayaan berfungsi sebagai bagian dari sistem yang juga meliputi fenomena lingkungan. Pendekatan pertama ini menjadikan praktek kebudayaan dapat dipahami dengan cara menunjukan bagaimana sesuatu bekerja. Pendekatan ini terutama tertarik pada deskripsi atau analisis sistemik; (2) menunjukkan bahwa fenomena lingkungan bertanggung jawab timbul dan berkembangnya perilaku kebudayaan. Pendekatan kedua ini menjadikan praktek kebudayaan dapat dipahami dengan cara mencoba menjawab pertanyaan mengenai evolusi kebudayaan tersebut. Pendekatan ini lebih menfokuskan pada asal mula dan perkembangan.

Kebudayaan muncul bila ada masyarakat, sebaliknya tidak ada masyarakat tanpa budaya, dimana setiap kebudayaan yang hidup dalam suatu masyarakat dapat berwujud sebagai masyarakat desa, sebagai masyarakat kota, sebagai kelompok kekerabatan, atau kelompok adat yang lain, biasa menampilkan suatu corak khas, terutama yang terlihat orang luar, bukan warga masyarakat yang bersangkutan (Kuncaraningrat, 1990:263). Demikian pula halnya dengan adat Melayu yang merupakan kebudayaan Melayu, karena ada masyarakat Melayu yang merupakan unsur pendukungnya.

Kebudayaan Melayu sarat dengan nilainilai kearifan eco-religio-culture ini dapat di lihat pada ungkapan tentang pemeliharaan hutan sebagai teladan sebagai berikut : 
Husni Thamrin, Zulfan Saam; ECO-Religio-Culture Suatu Alternatif Pengelolaan Lingkungan

"Kalau hendak tahu ragam manusia, tilik dan simak kayu di rimba.Adayang lurus ada yang bengkok. Ada yang condong ada yang tegak.Ada yang berbongkol ada yang licin. Ada yang berduri ada yang tidak. Ada yang gatal ada yang miang. Ada yang hidup tindih menindih. Ada yang hidup pilin berpilin. Ada yang hidup belit membelit. Ada yang hidup himpit menghimpit. Ada yang hidup jalar menjalar. Ada yang hidup tumpang menumpang. Ada yang menumpang sampai mati. Ada yang hidup melata tanah. Ada yang hidup menjadi pucuk. Demikian itu laku manusia. Dari dahulu sampai sekarang. (Effendi, 2004).

Setiap masyarakat merupakan wadah dari kebudayaan, yaitu suatu sistem yang menarik perikelakuan dari semua orang atau anggotanya kearah suatu inti dari sistem yang bersangkutan (Jajadiningrat, 2001:101-102). Semua makhluk hidup, termasuk manusia mempunyai pola tingkah laku yang sebagian ditentukan oleh hereditas, tetapi hanya manusia yang mengembangkan pola-pola tingkah laku sosial yang

dikukuhkan

\begin{tabular}{|l|c|}
$\begin{array}{l}\text { Pengetahuan } \\
\text { Kebudayaan }\end{array}$ & Eksplit \\
& Tasit \\
\hline
\end{tabular}

kebudayaan. Pola tingkah laku manusia didasarkan pada pengaruh biologis, sosial dan kultural. Keberadaan kebudayaan membawa implikasi lingkungan sosial dimana manusia dengan potensi bawaannya untuk bertingkah laku didorong untuk belajar bertingkah laku dengan cara-cara sebagai manusia.

Kebudayaan paling sedikit memiliki tiga wujud, yaitu: (1) sebagai suatu kompleks dari ide-ide, gagasan, nilai-nilai, norma-norma, peraturan dan sebagainya; (2) sebagai suatu kompleks aktivitas kelakuan berpola dari manusia dalam masyarakat;dan (3) sebagai benda-benda hasil karya manusia (Kuncaraningrat, 1974:15). Faktor yang mengaitkan integrasi masyarakat dengan ekologi adalah kependudukan atau demografi, yaitu manusia sebagai penduduk sesuatu daerah atau wilayah; kebudayaan teknologis, yaitu perkembangan kebudayaan dalam arti peralatan teknik dalam kehidupan; dan kebudayaan rohaniah, yaitu menyangkut nilainilai, adat-istiadat dan kepercayaan manusia dalam masyarakat itu, penggunaan sumbersumber daya alam, pembagian pekerjaan. Faktor integrasi dalam masyarakat itu akan menghasilkan pembagian ruang (geografi), fungsi pranata dan lembaga serta organisasi sosial, posisi dalam masyarakat, serta memberikan pengaruh timbal balik antara ekologi,budaya dan religi

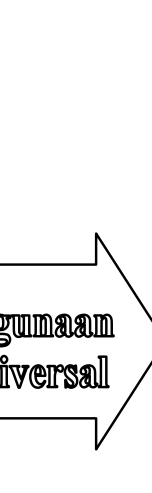

Perilaku Manusia dan Kebudayaan

Seperti ditunjukkan Gambar 1 pengetahuan kebudayaan terdiri dari dua level kesadaran. Kebudayaan ekplisit merupakan bagian dari yang kita ketahui, yaitu level pengetahuan dimana orang-orang dapat 
berkomunikasi dengan kerabat secara mudah. Pada saat yang sama porsi yang besar dari pengetahuan kebudayaan kita tetap tasit (dimengerti atau diterima tanpa diekspresikan secara terbuka), diluar kesadaran kita. Etnografi adalah studi yang mempelajari pengetahuan kebudayaan yang ekspilisit dan tasit.

Menurut Blumer dalam Spradley (1987:24), konsep kebudayaan pengetahuan yang diperoleh memiliki banyak kesamaan dengan interaksionisme simbolik dalam menjelaskan perilaku manusia kaitannya dengan maknanya yang mempunyai tiga premis: (1) tindakan manusia terhadap sesuatu berdasarkan makna yang dimiliki sesuatu tersebut. Orang-orang tidak bertindak terhadap sesuatu itu sendiri, melainkan terhadap maknanya; (2) terletak dalam interaksionisme simbolik adalah makna sesuatu yang diturunkan atau yang timbul dari interaksi sosial, seseorang memiliki pengikut. Kebudayaan, sebagai sistem makna yang dibagi, dipelajari, direvisi, dipelihara dan didefenisikan dalam konteks orang-orang yang berinteraksi. Kebudayaan dari setiap kelompok tidak bisa dihindari terikat dengan kehidupan sosial dari masyarakat setempat yang khusus; (3) makna ditangani, dimodifikasi melalui sebuah proses yang bersifat menerangkan digunakan orang-orang yang menangani sesuatu yang dihadapi. Jadi orang-orang bertindak dikendalikan dengan kebudayaanya.untuk mengetahui aspek yang bersifat menerangkan lebih jelas, jika menganggap kebudayaan sebagai peta kognitif. Dalam kegiatan yang berulang yang memperbaiki kehidupan setiap harinya, menunjuk pada peta. Peta ini merupakan pedoman untuk bertindak dan menginterpretasikan pengalaman. Peta tidak memaksa untuk mengikuti arah yang khusus. Kebudayaan tidak mencakup peta yang rinci, kebudayaan memberikan prinsip untuk menginterpretasikan dan memberi respon terhadap prinsip tersebut.

Semua kebudayaan mengandung tiga komponen utama, yaitu:

1. Komponen material, yang terdiri dari segala sesuatu yang bersifat material, misalnya: alat-alat kerja, perabot rumah tangga, bangunan, makanan, dan pakaian.

2. Komponen spiritual, yang merupakan kebudayaan rohaniah, seperti: nilai,norma, peraturan, sistem pendidikan, pengetahuan, ilmu, kepercayaan, dan konsep-konsep alam semesta.

3. Komponen simbolik, yang mengandung baik unsur material maupun unsur spiritual, dalam bentuk kode, bahasa, upacara, mimik, dan lain-lain (Sukadana, 1983:13).

Menurut ahli arkeologi yang berorientasi pada sistem, kebudayaan didefinisikan bukan sebagai campuran norma-norma dan artefak tetapi sebagai suatu sistem perilaku yang saling berinteraksi (Moran,1993:11). Penekanannya diberikan pada variabilitas, hubungan sebab akibat multivariasi dan proses. Dalam arkeologi, pendekatan ekosistem dibuktikan sebagai alat penyelidikan yang berguna untuk mengalahkan ahli-ahli arkeologi untuk berikir dalam hal interelasi-interelasi sistemik.

Secara konseptual yang dimaksud kebudayaan adalah salah satu cara manusia untuk melakukan adaptasi terhadap lingkungannya, yang merupakan tindakan berpola dalam suatu masyarakat, meliputi hampir semua aktifitas manusia dan dihasilkan dari proses belajar bukan melalui warisan biologis, dimana kebudayaan juga merupakan seperangkat sistem nilai, tata hidup dan sarana bagi manusia dalam kehidupannya. Kehidupan manusia bersifat dinamis, yang menyebabkan kebudayaan 
Husni Thamrin, Zulfan Saam; ECO-Religio-Culture Suatu Alternatif Pengelolaan Lingkungan

antar generasi mengalami perbedaan akibat adaptasi yang dilakukan.

Aspek yang penting dari proses pembudayaan adalah pewarisan nilai-nilai dan norma-norma. Nilai-nilai adalah sesuatu yang diakui orang berdasarkan perasaan sebagai sesuatu yang tersusun rapi. Berkaitan dengan ini dapat dilihat dalam ungkapan kearifan lingkungan peladangan orang Melayu Melayusebagai berikut :

"Ada apa dengan tanah peladangan.Tempat berladang sepanjang buat.Tempat menanam padi beragam. Tempat berpindah berganti musim. Walau berpindah disitu juga, walau beralih kesana juga. Beralih tidak merusak rimba, berpindah tidak merusak alam, bersalin tidak merusak sungai, berganti tidak merusak gunung.Ladang dibuat menuruti adat. Ada disebut adat berbanjar.Ada disebut adat bersolang. Ada disebut adat bertobo. Ada disebut adat bepiari.Ada disebut adat betayan.Ada disebut adat membenih.Ada disebut adat membakar".

(Sumber : Wawancara dengan Datuk Samuel, 73 tahun, 15 Agustus 2013)

Orang Melayu dapat berbuat terhadap nilai kearifan lingkungan dengan jalan memikirkan, mengakui,menghargai dan mendorongnya dalam pelaksanaan kehidupan sehari-hari. Menurut Spradley, nilai adalah konsepsi buatan manusia mengenai apa yang diinginkan dalam pengalaman manusia (Spradley,1987:5). Nilai merupakan sesuatu yang menarik, sesuatu yang dicari, sesuatu yang menyenangkan, sesuatu yang di sukai dan diinginkan, singkatnya sesuatu yang baik (Bertens,2001:139). Nilai-nilai itu sangat penting artinya bagi kestabilan suatu masyarakat. Yang terpenting dari nilai tersebut adalah solidaritas dan nilai kekuasaan. Sedangkan yang dimaksud dengan norma adalah aturan atau kaedah yang kita pakai sebagai tolak ukur untuk menilai sesuatu (Bertens,2001:1). Norma merupakan patokan perilaku dari semua anggota masyarakat, yang mengatur interaksi antar individu yang berisi dua komponen penting: (1) kesepakatan antara kelompok anggota masyarakat tentang tingkah laku yang dijalankan atau tidak boleh dijalankan; (2) mekanisme pelaksanaan kesepakatan tersebut. Norma-norma perilaku dibedakan dalam cara-cara berbuat dari orang biasa (folkway), seperti: menepati janji, memberikan sesuatu dengan tangan kanan. Folkway dipandang tidak begitu penting dan hukumnya pun ringan andaikan di langgar, berbeda halnya dengan mores yang dipandang sangat penting dan pelanggarannya mendapat hukuman.

Nilai selalu memiliki konotasi positif, nilai biasa berkaitan dengan moral, yang biasanya berkaitan dengan pribadi manusia yang bertanggung jawab. Sedangkan norma terdiri dari bermacam-macam, ada yang menyangkut benda ataupun tingkah laku manusia.Setiap kelompok manusia mempunyai cara dan pola hidup yang bervariasi, khas sesuai situasi dan kondisi masing-masing kelompok yang merupakan karakteristik dari suatu kebudayaan tertentu.Secara konseptual yang dimaksud dengan nilai adalah konsepsi buatan manusia, biasanya sesuatu yang bermakna positif (baik) karena berkaitan dengan moral.Sedangkan norma adalah aturan yang dipakai untuk mengukur nilai tersebut, yang merupakan patokan dari semua anggota suatu masyarakat.

Berkaitan hal diatas ini sejalan dengan ungkapan kearifan lingkungan orang Melayu yang mengandung nilai-nilai filosofi eco-religioculture orang Melayu ini dapat dilihat pada ungkapan sebagai berikut :

"Apa tanda "Kepungan Sialang". Tempat Sialang rampak dahan. Tempat lebah membuat sarang. Tempat beradat dan 
berlembaga Rimba dipelihara dengan adat, hutan dikungkung dengan lembaga. Kayunya disimpai dengan undang. Rimba tak boleh ditebang tebas. Rimba tak boleh rusak binasa. Rimba larangan zaman berzaman.Rimba pusako turun temurun. Rimba soko rimba pilihan. Rimba tempat melepas adat. Rimba tempat menjunjung lembaga. Rimba tempat mencari teladan".

(wawancara dengan Tennas Efendi, Juli 2013)

Ungkapan-ungkapan diatas memberikan rekonstruksi eco-religio-culture tentang peliharaan hutan. Dalam ungkapan diatas hutan berfungsi sebagai tempat ekosistem sialang. Ekosistem sialang sangat ditentukan oleh keadaan hutan. Dalam masyarakat Melayu Melayumempunyai fungsi yang sangat vital.

Dalam ungkapan diatas disebutkan juga didalam hutan disebutkan dalam hutan terlembaganya adat. Hutan rimba di pelihara dengan adat, kayunya diatur penggunaan melalui undang undang. Hutan tidak boleh ditebas, maksudnya hutan tidak boleh ditebang sembarangan. Hutan tidak boleh dirusak, karena di dalam hutan tempat penyangga ekosistem lingkungan, tempat hidup flora dan fauna. Hutan dalam masyarakat Melayusudah ada sejak turun temurun, sejak zaman kesultanan dan kolonial. Namun yang sangat menyedihkan adalah keadaan hutan yang telah mengalami dagradasi. Hutan selain berfungsi sosialekonomi juga berfungsi ekologis seperti mengatur tata air (hidrologi), fungsi lindung, penyerap karbon dan sumber daya alam dan keanekaragaman hayati lainnya. Menurunnya luas hutan baik akibat konversi lahan, penebangan (illegal logging) maupun kebakaran hutan dan lahan tentunya sangat berdampak baik dari segi sosial ekonomi, ekologi, kesehatan maupun hubungan baik dengan negara tetangga. Isu perusakan hutan yang terjadi bisa saja menurunkan kredibilitas suatu bangsa dalam hubungan komunitas internasional. Disamping itu, isu kerusakan hutan juga dapat berdampak pada sektor ekonomi seperti pemboikotan pemasaran produk dari Indonesia.

\section{Eco-Religio-culture dalam Tanah Adat}

Hutan Tanah Adat merupakan sesuatu yang mempunyai arti penting dalam kehidupan manusia. Di dalam masyarakat Melayutanah mempunyai makna penting, yaitu sebagai sumber dasar ekonomi,lingkungan hidup, kekuatan politk, dan sekaligus sebagai simbol status sosial. Tanah merupakan tempat anggotanya lahir, tempat memperoleh sumber makanan dan akhirnya tempat anggota dikuburkan. Kedudukan tanah di Melayuantara lain (1) tanah komunal (customary land) diwilayah pesisir Timur Riau disebut dengan istilah hutan tanah, sedang di Riau daratan disebut dengan tanah adat yang terbagi kepada dua, yaitu tanah komunal persukuan dan tanah komunal negeri; (2) tanah pusaka (pusako) terbagi kepada dua yaitu pusaka tinggi dan pusaka rendah; (3) tanah hak pakai.

Tanah milik rakyat yang diikat dengan ketentuan adat dan peraturan masyarakat dikenal dengan istilah tanah komunal. Pada awalnya tanah komunal dapat diartikan sebagai tanah persekutuan hukum masyarakat yang di atasnya, diakui hak-hak mereka baik secara bersama-sama sebagai suatu kesatuan, maupun hak pribadi sebagai anggota persekutuan sebagai wilayah lingkungannya.

Menurut ketentuan adat, tanah komunal ini adalah untuk keperluan dan kesejahteraan anggota persukuan (penduduk) masyarakat yang diatur penggunaannya oleh pimpinan adat. Masyarakat adatboleh memanfaatkan 
Husni Thamrin, Zulfan Saam; ECO-Religio-Culture Suatu Alternatif Pengelolaan Lingkungan

tanah adat setelah mendapat izin secara sah dari pimpinan adat atau penghulu suku. Bilamana masyarakat adat mau membuka hutan tanah untuk perladangan dan perkebunan maka mereka harus meminta izin dari pimpinan adat. Selain itu masyarakat adat diharuskan membayar semacam 'sewa tanah' atau yang disebut sebagai pancung alas. Mengikut hukum adat, anak kemenakan, yang membuka tanah komunal harus mematuhi hukum yang ada. Di antara peraturan luas tanah yang diperuntukkan bagi satu keluarga ialah dua hektar, mereka harus membuat parit pembatas tanah dan tanah yang telah dibuka harus digunakan sebagai kawasan pertanian, perladangan, dan perkebunan. Disini tata kelola ekologis telah diatur sedemikian rupa untukmenjaga lingkungan yang berkelanjutan baik yang telah tertulis maupun tidak.

Hukum adat juga menetapkan tanah komunal yang sudah diberi izin untuk dibuka harus dikerjakan. Jika sampai tiga tahun tanah tersebut tidak dikerjakan izin untuk mengusahakan tanah tersebut akan lepas dan hak kuasa ke atas tanah tersebut kembali kepada pimpinan adat yang mengepalai suku, gabungan beberapa kelompok keluarga yang didasarkan pada prinsip adat setempat. Setiap suku dipimpin oleh seorang penghulu suku yang disebut sebagai pimpinan adat. Selanjutnya pimpinan adatboleh memberikan hak penguasaan tanah itu kepada masyarakat adatyang lain. Dalam hal inilah selalu timbul kesalahfahaman antara masyarakat adat tentang tanah komunal yang mereka pernah kerjakan. Mereka berpandangan bahwa hak ke atas tanah tersebut boleh diwariskan kepada generasi yang berikutnya. Hukum adat menentukan bahwa tanah tersebut berbentuk hak pakai bukan sebagai hak milik. Pimpinan adat sebagai penghulu suku menetapkan tanah itu sebagai hak komunal yang dikuasai oleh masyarakat adat, komunitas yang tinggal dalam suatu wilayah dan mempuyai ketentuan adat secara turun-temurun karena tanah komunal merupakan hak pakai bukan hak milik.

Dalam perubahan sosial yang terjadi dewasa ini, masyarakat Melayumenghadapi beberapa persoalan tanah. Di antaranya adalah masalah tanah adat itu sendiri. Masalah tanah ini muncul karena beberapa faktor:

a. Semakin sempitnya lahan pertanian

b. Semakin bertambahnya jumlah penduduk

c. Kurang jelasnya batas antara tanah adat yang dikuasai oleh masyarakat adat dengan tanah yang dikuasai oleh pemerintah dan swasta

d. Semakin berkembangnya kawasan perkebunan kelapa sawit akibat adanya investor dari dalam maupun dari luar negeri.

e. Harga tanah yang meningkat dengan cepat.

f. Kondisi masyarakat yang semakin sadar dan peduli akan haknya.

g. Situasi keterbukaan yang digariskan pemerintah setelah reformasi.

Beberapa masalah yang berhubungan dengan tanah adat (komunal) di Rokan Hilir, ada hubungannya dengan perubahan sosial yang terjadi dalam masyarakat adat. Di antara perubahan yang telah terjadi adalah tentang kedudukan pimpinan adat sebagai penghulu suku, kekuasaan dan wibawanya yang sudah mulai berkurang sebagai pemimpin tradisional. Hal ini disebabkan karena pimpinan adat tidak lagi memegang amanah sebagaimana ketentuan hukum adat. Pimpinan adat yang seharusnya menjaga dan memelihara harta anak kemenakan, tetapi pimpinan adatmalah menjual tanah adat kepada investor yang bergerak dalam sektor 
perkebunan kelapa sawit. Perubahan sosial telah mengelirukan pimpinan adat akan hak dan tanggungjawabnya sebagai pimpinan suku. Ini disebabkan pimpinan adat terpengaruh oleh kepentingan ekonomi, juga adanya campur tangan investor sebagai pemodal terhadap penguasa tradisional yaitu pimpinan adat. Satu perkara yang nampak sekarang ialah ramai masyarakat adat yang mulai meninggalkan nilai-nilai tradisional dan tidak lagi mematuhi hukum adat. Akhirnya masyarakat adat juga kurang mempunyai ketergantungan dengan pimpinan adat sebagai penghulu suku.

Dari penjelasan di atas dapat dilihat bahwa masalah nilai-nilai pelestarian lingkungan tanah adat di daerah Riau pada asasnya ada hubungannya dengan perubahan sosial dan sistem kekerabatan yang terdapat dalam masyarakat. Perubahan itu terlihat dalam cara kepemilikan serta pemanfaatan tanah komunal dan peranan pimpinan adat sebagai penghulu pemimpin masyarakat adatdalam kepemilikan tanah komunal.

Fungsi tanah adat sebagai pusaka tinggi mempunyai beberapa fungsi utama dalam masyarakat daerah RokanHilir di antaranya sebagai berikut.

\section{Sosio-Kultural-Religius}

Dalam masyarakat di daerah Melayutanah dipandang sebagai identitas kultural (cultural identity). Identifikasi diri (self identification) seseorang,sebagai orang yang menganut adat istiadat dihubungkan dengan suku dan negerinya juga dikaitkan dengan tanah. Sesuai dengan pepatah adat kalau terpelihara hutan dan tanah banyak manfaat besar faedah, bila tersesak panjanglah langkah, bila sempit lari ketanah;apabila rusak hutan dan tanah sekitar, sempit tidak dapat berlegar,goyah tidak dapat bersandar,panas tidak dapat mengekas,hujan tidak dapat berjalan, teduh tidak dapat berkayuh, air kering kerontang, musnahlah alam dan manusia.Tanah sebagai sumber kehidupan, sumber air, kita berasal dari tanah, memelihara tanah dan kembali ketanah. (Wawancara dengan Hasan Basri, di Bangko Pusako, tanggal 27 Agustus 2012).

Oleh karena itu, orang RokanHilir harus bisa selain menjelaskan tanah adat juga mampu menunjukkan dimana letak kawasan sumber mata air, kawasan tanah pertanian dan pusara (pemakaman) kaum atau suku mereka. Identitas suku dan negeri asal merupakan identitas kultural yang dikonstruksikan atau digambarkan secara sosial mitologi. Identitas tanah adat memiliki arti bahwa seseorang mempunyai hubungan geneologis dalam pembentukan ruang untuk hidup bersama.

Sedangkan kita berasal dari tanah dan kembali ketanah dipandang penting oleh masyarakat Melayukarena ada hubungkait dengan prasyarat kehidupan dan simbol kewujudan orang Melayuitu sendiri. Sumber air dan tanah merupakan syarat utama untuk kelangsungan hidup, sedangkan tempat pemakaman menunjukkan pada suatu identitas diri sesudah mati dari suatu kaum atau suku. Tanah sebagai lambang ikatan kaum yang bertali darah atau hubungan darah supaya hubungan darah jangan terputus sehingga tanah adalah hal yang sangat terpenting dalam kehidupan masyarakat Rokan Hilir.

Sistem budaya masyarakat Melayufungsi sosial-budaya-religio yang baik untuk mengelola lingkungan secara harmonis. Dalam sistem budaya orang Melayudapat dilihat dengan jelasbagaimana nilai-nilai budaya memberi pedoman dan arah agar lingkungan terpelihara. Semuanya terkandung dalam berbagai aspek budaya, baik secara 
Husni Thamrin, Zulfan Saam; ECO-Religio-Culture Suatu Alternatif Pengelolaan Lingkungan

lisan maupun dalam tindakan perbuatan yang nyata.

Orang Melayu yang berladang di daerah rawa-rawa mempunyai kebiasaan menanam rumbia dan rumbai di tepi ladang mereka. Tanaman rumbia telah membuat ladang mereka mendapat cadangan simpanan air ketika tiba musim kemarau karena tanaman ini dapat menyimpan air. Sementara itu, rumbia dapat di jadikan barang anyaman, diantaranya dibuat jadi ago untuk alat pengangkut padi. Pohon-pohon rumbia lebih banyak lagi kegunaannya. Daun rumbia dijadikan atap, sedangkan sagunya bisa diolah menjadi bahan makanan kalau ladang mereka tidak selamat.

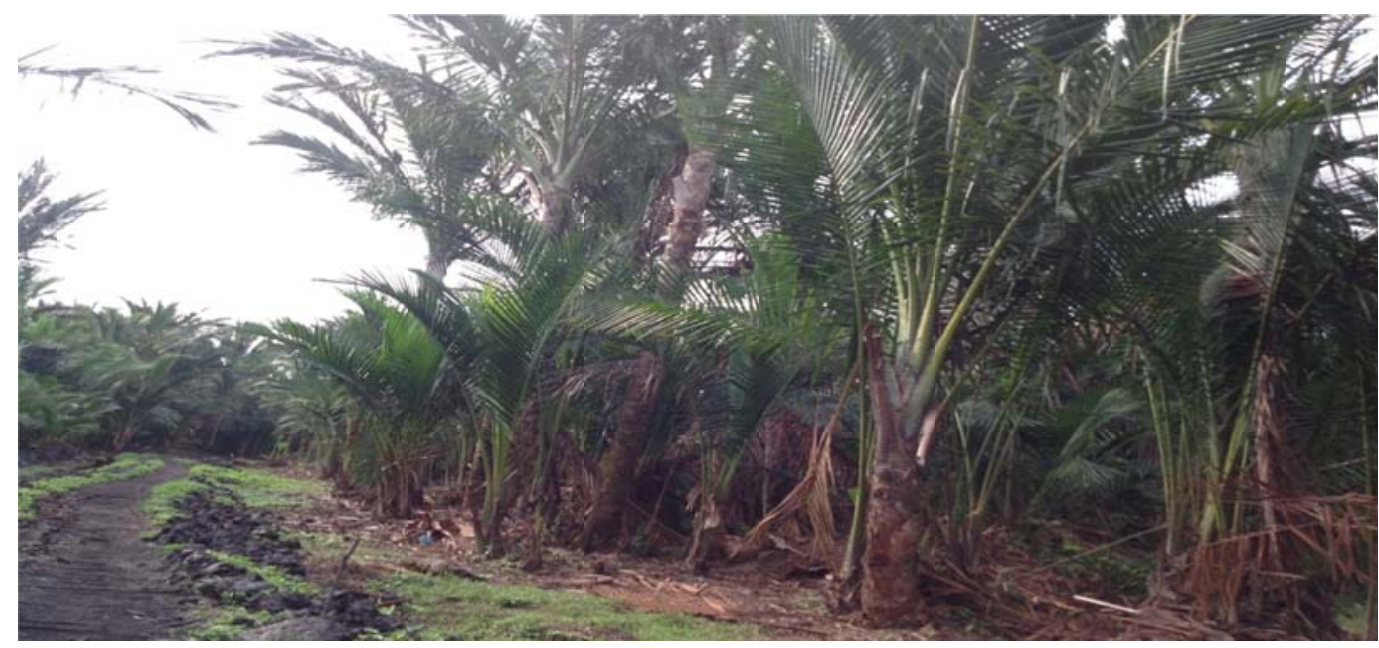

Gambar 2

Kebun Rumbia Kearifan Ekologis Melayu

Tradisi menjaga kelestarian tumbuhtumbuhan misalnya dapat dilihat pada tradisi menjaga pohon durian yang terdapat di perkampungan orangMelayu di Rokan Hilir. Apalagi di kampung daerah aliran sungai sebagai tempat yang disukai durian. Jika durian sudah berbuah, orang Melayu punya tradisi mengambil buah durian dengan tidak dipanjat, tetapi dibiarkan jatuh buah yang sudah masak. Jika ada orang (terutama anakanak) hendak memanjat, akan diberi peringatan bahwa durian yang dipanjat tidak akan berbuah lagi, malah batangnya akan mati.

Larangan yang berisi mitos perlu diadakan penelitian relatif mendalam terhadap kebenarannya. Namun yang penting, dengan larangan itu durian akan dibiarkan masak, tidak dipanjat yang akan menyebabkan durian muda tidak akan diambil (rusak). Tradisi ini penting untuk kelestarian pohon durian yang masak mempunyai biji yang siap di tanam. 


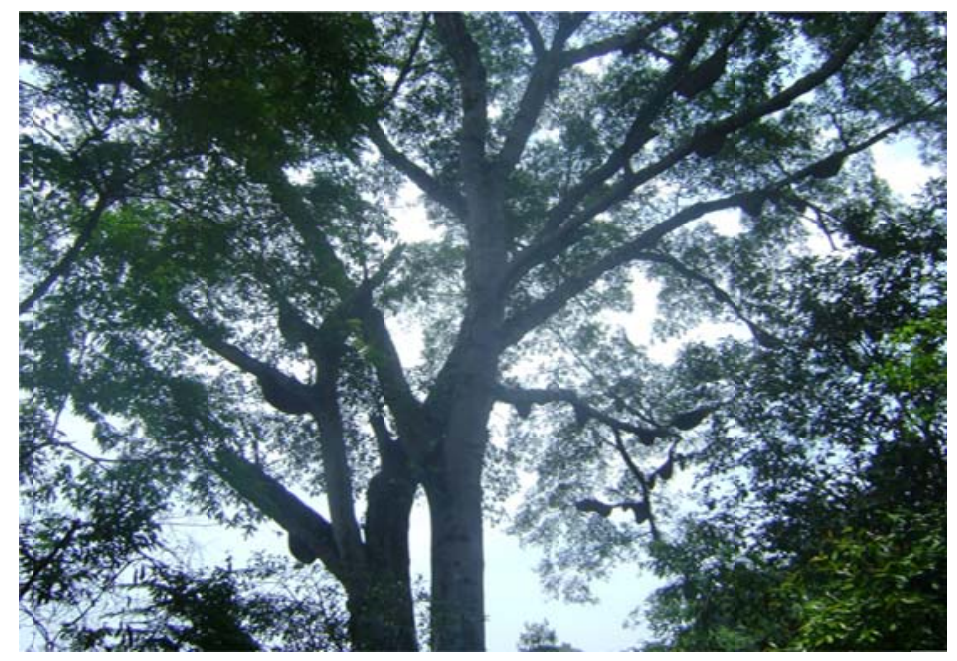

Gambar 3

Pohon Sialang di Hutan Tanah Adat Orang Melayu

Tradisi lain untuk menjaga kelestarian lingkungan seperti menjaga pohon sialang, pohon yang menjadi tempat bersarang lebah.Kayu sialang ada yang berupa cempedak air (tumbuh di tebing sungai), kayu ara, kempas, suluh batang dan sebagainya. Mengambil madu lebah tidak boleh sembarangan. Lebah tidak boleh dibinasakan untuk mengambil madunya. Untuk kepentingan ini diadakan suatu upacara yang dipimpin oleh seorang dukun dan perangkatnya yang di beri tugas mengambil madu lebah. Dia dapat mengambil madu lebah dengan aman dengan mendekatkan asap tunam kepada lebah. Ketika lebah kena oleh asap, maka lebah menghindar. Dengan demikian madunya mudah diambil.

Tentu atas kesadaran betapa besarnya manfaat lebah sialang, maka kayu sialang tempat lebah berkembang biak tidak boleh ditebang begitu saja menurut adat orang Rokan Hilir. Siapa yang kedapatan menebang pohon sialang dengan alasan yang tidak kuat, akan kena denda dengan menyerahkan kain puth sepanjang kayu sialang yang telah ditebangnya.
Kearifan dalam memelihara fauna dalam menjaga keseimbangan ekologis dapat dilihat dengan memberlakukan hewan musang, sebenarnya menjadi musuh ternak ayam. Namun, binatang ini tidak pernah diberantas oleh orang Melayu Melayusampai punah. Meskipun musang dapat mengancam ternak ayam dan itik, tetapi ada peranannya terhadap kelestarian lingkungan. Musang suka makan buah-buahan, terutama buah enau, kopi, dan biji-bijian lainnya. Setelah memakan buah-buahan ini, terutama buah enau dan kopi,biji-bijian ini akan tersebar kemana-mana dan siap tumbuh di tempat itu, sesuai dengan kemana binatang ini membuang kotoran. Oleh karena itu jarang orang Melayu menanam enau dengan sengaja bahkan juga pohon buah yang orang Melayu tradisional telah memperlakukan alam bagaikan manusia, sehingga ada sentuhan emosi dalam hubungan manusia dengan alam. Baik enau maupun padi telah diperlakukan sebagai perempuan. Enau telah ditetek (diolahtandannya) sehingga menghasilkan air enau yang di sebut air nio(nira). Air nira dapat dijadikan manisan dan gula enau. Oleh karena itu, enau telah 
menjadi sumber gula yang penting sejak zaman dulu, sebelum orang mengenal gula pasir dari tebu.

Buah padi semasa belum dituai untuk menjaga semangatnya tidak disebut buah padi tetapi buah rumput. Ini mengandung saran makna kehati-hatian, sehingga petani tidak terlanjur merasa bahagia (apalagi sombong) sebelum hasil ladangnya sampai selamat ke rumah. Sebelum padi dituai, diadakan upacara menjemput padi. Sawah atau ladang dikelilingi dengan asap tunam oleh tukang jemput. Sambil berjalan mengelilingi ladang, dia memanggil padi dengan bahasa yang indah, bagaikan memanggil seorang perempuan agar segera pulang ke rumahnya.

Keberhasilan petani dengan hasil ladang merupakan suatu rahmat yang tidak ternilai. Selama 6 bulan, ladang itu telah diperlihara siang dan malam oleh petani. Ketika panen sudah selesai, maka petani berdo'a di rumahnya sebagai tanda bersyukur kepada Tuhan. Kemudian dihidangkan beras baru yang harum baunya (sementara padi yang tidak dijemput dengan upacara dipercayai tidak akan harum bau nasinya). Sewaktu akan makan, dipesankan kepada anak-anak agar nasi jangan sampai jatuh ke lantai. Nasi yang jatuh dikatakan akan menangis karena telah dibuang dengan siasia padahal untuk mendapatkan sebutir nasi, diperlukan masa berladang 6 bulan. Hal ini memberikan dorongan kepada anak-anak untuk hidup hemat.

Orang Melayumemberi kearifan kepada anak cucu dan kemenakannya, agar menjaga dan memelihara alam lingkungan. Telah dikumpulkan bidal, gurindam dan pantunnya misalnya dapat dilihat dibawah ini :

"Kalau hidup hendak selamat.Peliharalah laut dengan selat.Peliharalah tanah berhutan lebat. Di situlah terkandung rezki dan rahmat. Disitulah terkandung tamsil ibarat. Disitulah terkandung aneka nikmat. Tanda orang memegang adat. Alam dijaga betul diingat. Tanda orang memegang amanah, pantang merusak hutan dan tanah.Tanda orang berpikir panjang, merusak alam ia berpantang. Tanda orang berakal senonoh, menjaga alam hatinya kokoh.Tanda orang berbudi pekerti, merusak alam ia jauhi.Tandaingat ke anak-cucu,merusak hutan haitnya malu.Tanda ingat kehari tua, laut dijaga bumi dipelihara.Tanda ingat ke hari kemudian, taat menjaga laut dan hutan.Tanda ingat kepada Tuhan, menjaga alam ia utamakan. Tanda ingat hidupkan mati, memanfaatkan alam berhati-hati. Tanda ingat adat lembaga, laut dikungkung hutan di jaga.Siapa yang mengenang anak-cucunya, bumi yang kaya takkan di rusaknya. Siapa sadar dirinya khalifah, terhadap alam takkan menyalah.Apa tanda hidup berilmu, memeliharanya alam ianya tahu. Apa tanda hidup terluji, alam sekitar ia santuni. Apa tanda hidup menenggang, menjaga alammengikuti undang.

Adat hidup orang beriman.Tahu menjaga laut dan hutan. Tahu menjaga kayu dan kayan. Tahu menjaga binatang hutan. Tebasnya tidak menghabiskan. Tebangnya tidak memusnahkan. Bakarnya tidak membinasakan" (Effendi, 2004).

Dalam pandangan orang Melayu di hidup hendaklah dilandasi oleh agama, adat dan resam yang baik. Adat bertumpu pada agama, bagaikan tiang berpijak pada sendirinya. Jika tidak begitu, hidup akan binasa, ibarat tiang tanpa sendi, akan lapuk dimakan karat. Agama memberi panduan hidup dan mati, adat mengawal agar hidup mulia sedangkan resam (tradisi) membuat 
Husni Thamrin, Zulfan Saam; ECO-Religio-Culture Suatu Alternatif Pengelolaan Lingkungan

hubungan harmonis dengan alam. Maka, orang yang beriman, beradat dan beresam yang baik, akan memelihara hubungan dengan Tuhan, manusia dan alam sebab tidak ada satupun yang diciptakan Tuhan dengan sia-sia. Inilah jalan manusia menuju menjadi makhluk mulia, sebagaimana tertulis dalam kata bersajak berikut ini.

"Adat hidup memegang adat.Tahu menjaga laut dan selat. Tahu menjaga rimba yang lebat.Tahu menjaga tanah ulayat. Tahu menjaga semut dan ulat. Tahu menjaga togok dan belat. Tahu menebas memegang adat.Tahu menebang memegangamanat. Tahu beladang menurut undang.Tahu berkebun mengikut kanun. Beramu tidak merusak kayu.Berotan tidak merusak hutan. Bergetah tidak merusak rimba.Berumah tidak merusak tanah. Berkebun tidak merusak dusun.Berkampung tidakmerusak gunung. Berladang tidak merusak pedang. Adat hidup memegang amanah.Tahu menjaga hutan dan tanah. Tahumenjaga bukit dan lembah.Berladang tidak merusak tanah. Berkebun tidak merusak rimba" (Wawancara dengan Hasan Basri, 57 tahun, tokoh Adat Bangko dan Tennas Efendi,2004).

Manusia harus menyadari dia berada dimuka bumi sebagai khalifah,yakni seorang yang bertindak sebagai pemelihara segala kekayaan Tuhan.Dia muncul bukan untuk mengharu-biru, demi ambisi dan nafsu serakahnya tetapi bertindak bijaksana melestarikan hutan tanah, air, flora dan fauna, sehingga mendapat sebesar-besar manfaat dari situ. Ini dapat dilihat dalam penuturan informan di lapangan sebagai berikut :

"Kalau terpelihara hutan tanah. Banyak manfaat besar faedah. Bila tersesak panjanglah langkah.Bila sempit lari ketanah. Kalau terpelihara alam lingkungan. Banyak manfaat dapat dirasakan. Ada kayu untuk beramu.Ada tumbuhan untuk ramuan. Ada hewan untuk buruan.Ada getah membawa faedah.Ada buah membawa berkah. Ada rotan penambah penghasilan.Kalau terpelihara alam sekitar. Manfaatnya banyak, faedahnya besar.Di situ dapat tempat bersandar. Di situ dapat tempat berlegar.Di situ dapat membuang lapar.Di situ dapat didengar.Di situ kecil menjadi besar. Di situ sempit menjadi lebar."

Wawancara dengan Penghulu Alju di Rantau Bais, Tanah Puth, 17November 2014).

Ketika manusia tidak dikawal dengan agama, tidak dipandu dengan adat, dan tidak mempunyai tradisi yang baik, maka dia akan mendatangkan bencana. Namun kemudian, kerusakan itu akan berbalik mengancam manusia itu sendiri. Ini yang akan mempercepat kiamat dari sudut pandang budaya manusia, meskipun kiamat yang sebenarnya adalah rahasia Allah semata. Keadaan ini sudah dibidal oleh orang patut Melayu dalam rangkaian kata yang puitis.

"Apabila rusak alam sekitar. Sempit tidak dapat berlegar. Goyah tidak dapat bersandar.Panas tidak dapat mengekas. Hujan tidak dapat berjalan. Teduh tidak dapat berkayuh. Apabila alam sudah binasa. Bala turun celaka tiba. Hidup melarat terluntalunta.Pergi ke laut malang menimpa. Pergi ke darat miskin dan papa. Apabila alam menjadi rusak.Turun temurun hidupkan kemak. Pergi ke laut di telan ombak. Pergi kedarat kepala tersundak. Hidup susah dadapun sesak. Periuk terjerang nasi tak masak. Apabila alam menjadi punah. Hidup dan mati takkan semenggah. Siang dan malam ditimpa musibah. Pikiran kusut hati gelebah.Apabila rusak alam lingkungan. Di situlah puncak segala kemalangan. Musibah datang berganti-gantian. Celaka melanda tak berkesudahan. Hidup sengsara binasalah 
badan.Cacat dan cela jadi langganan. Hidup dan mati jadi sesalan. Apabila alam porak poranda, di situ tumbuh silang sengketa. Aib datang malu menimpa" (Effendi, 2004).

\section{Kosmologis-Ecologis-Religius}

Fungsi sosial kosmis orang Melayu tradisional dalam pemeliharaan lingkungan bersumber dari dukun, bomo, pawang, kemantan, guru silat, tokoh adat, para raja,dan ulama (memelihara umat dengan ajaran dan nilai Islam). Mereka mempunyai peranan masing-masing dalam masalah melestarikan lingkungan hidup. Dari nilai dan ajaran Islam, orang Melayu mengetahui bahwa tiap manusia dikawal atau diawasi oleh malaikat. Dalam wawancara peneliti dengan dukun Melayu, Manan (54 tahun) membuat analogi atau mitos bahwa tiap makhluk hidup berupa binatang liar dan burung dikawal oleh makhluk halus bernama sikodi,sejenis makhluk hidup yang tinggal di hutan belantara. Dari pandangan tradisional serupa ini, tidak ada warga yang berani semena-mena begitu saja mengambil apalagi merusak flora dan fauna. Jika mereka merasa memerlukannya, mereka meminta bantuandan petunjuk para dukun sehingga merasa aman mengambilnya.

Untuk memperkuat perlindungan alam lingkungan itu sehingga flora, fauna, tanah dan laut tidak diperlakukan begitu saja oleh tangan-tangan jahil. Para dukun dan tetua Melayu masa silam membuat bermacam cerita mengenai binatang, burung, pohon, sungai dan laut. Benda apapun yang disentuh oleh makhluk halus bisa mempunyai kekuatan gaib sehingga disebut juga puaka (sacral). Informan Hasan (57 tahun, Dukun di Bangko) mengatakan pada tempat tertentu yang memberi peluang untuk dihuni oleh makhluk halus, seperti sungai,tanjung, lubuk dan beting disebut keramat karena dipercaya dapat memberi petaka jika diperlakukan sesuka hati. Benda keramat seperti keris, tidak boleh disalahgunakan. Tempat-tempat sakral dan kuburan orang saleh disebut keramat sehingga tidak boleh dipakai untuk tempat mendirikan bangunan. Dengan demikian, barang dan kawasan tertentu ini mendapat keamanan dengan sendirinya sebab tak ada orang Melayu yang berani mengganggunya. Kepentingan warga masyarakat terhadap para dukun dalam masyarakat tradisonal cukup besar.

Mereka memerlukan keamanan menghadapi medan hidupnya, seperti membuka ladang, mendirikan rumah, turun ke laut, memasuki hutan belantara dan sebagainya. Dalam hal ini hanya para dukun yang dapat membantu mereka. Kemudian ada lagi yang lebih penting, yakni penyakit yang datangnya tak dapat diduga. Peranan dukun sangatlah menentukan ketika ada serangan penyakit. Oleh karena para dukun memberi pengobatan dengan menggunakan berbagai ramuan, maka orang Melayu tradisional menanam dan memelihara berbagai tanaman yang dapat berkhasiat menjadi obat. Beberapa tanaman itu adalah cekur (kencur), si tawar, si dingin, kumpai, daun salam, belai, jangau, kumis kucing, bunga kecubung, bunga raya, batang jarak, kunyit, sirih, tembakau, pinang, gambir dan lain-lain.

Dalam hal pemeliharaan hutan tanah adat, pimpinan adat Melayu telah membuat semacam tata ruang untuk masyarakat adat. Adapun mengenai hutan itu ditetapkan paling kurang ada 4 bagian yaitu:
a. Rimba simpanan atau rimba larangan.
b. Tanah kebun dan peladangan.
c. Rimba kepungan sialang.
d. Tanah perkarangan. 
Husni Thamrin, Zulfan Saam; ECO-Religio-Culture Suatu Alternatif Pengelolaan Lingkungan

Rimba simpanan adalah hutan belantara yang sengaja di biarkan lestari begitu rupa. Oleh karena tidak boleh siapa saja menjadikannya tanah produksi seperi dijadikan kebun dan ladang, maka disebut juga hutan larangan. Hasil-hasilnya dalam kayu perumahan (bangunan) berbagai buahbuahan, rotan, binatang buruan, berjenis burung dan ikan. Hasil-hasil ini boleh diambil atas sepengetahuan lembaga adat atau seizinpemangku adat yakni Penghulu atau Datuk Adat.

Hasil hutan belantara itu bisa diambil dalam batas tidak merusak kelestariannya. Oleh karena itu, dalam pemeliharaannya terkenal dengan bidal orang Melayu Melayukayu diganti kayu. Jadi pengambilan hasil-hasil itu masih dalam batas kemampuan belantara itu untuk bertahan, tidak rusak binasa.

\section{Sosial-Religio -Ekonomis}

Pada masyarakat di daerah Rokan Hilir, tanah dapat dijadikan sebagai simbol dari status sosial seseorang atau suku. Semakin banyak tanah pusaka yang dimiliki seseorang, semakin tinggi status sosial seseorang atau sukunya. Sebab jumlah tanah pusaka yang dimiliki mempunyai hubungan dengan kedudukan seseorang sebagai penduduk asal. Sebaliknya, seseorang yang berasal daripada orang atau kaum pendatang disebut dengan malakok (menyatu dengan suku asal) akan memiliki lebih sedikit tanah pusaka, sesuai dengan pepatah adat :

Masyarakat pesukuan atau puak yang tidak memiliki hutan tanah adat, adalah ibarat manusia yang tidak mempunyai rumah, ibarat lebah yang tak bermadu, ibarat ayam yang tak bereban, ibarat semut yang tak bersarang, ibarat kerbau yang tak berpadang. Ketidakpunyaan hutan tanah adat, mereka dapat disamakan dengan hewan yang berkeliaran, kerena mereka dianggap rendah tidak memiliki tanggungjawab terhadap anak cucu serta tidak memiliki tuah dan manwah. Selanjutnya disebutkan ke laut ia akan hanyut, ke darat ia akan melarat, ke hulu akan mendapat malu, ke hilir ia akan terkikir ...

(Wawancara dengan Tokoh Adat Rohil, Datuk Indra, Bagan Siapi-api, 7 Juli 2012)

Maksudnya, jika masyarakat mempunyai bayak emas apa yang diingini dapat tercapai karena jika berkekurangan emas boleh digadaikan atau dijual dan mempunyai harga yang tinggi, jadi orang yang mempunyai emas digolongkan kepada masyarakat yang mempunyai strata yang lebih tinggi daripada masyarakat yang tidak ada emas.

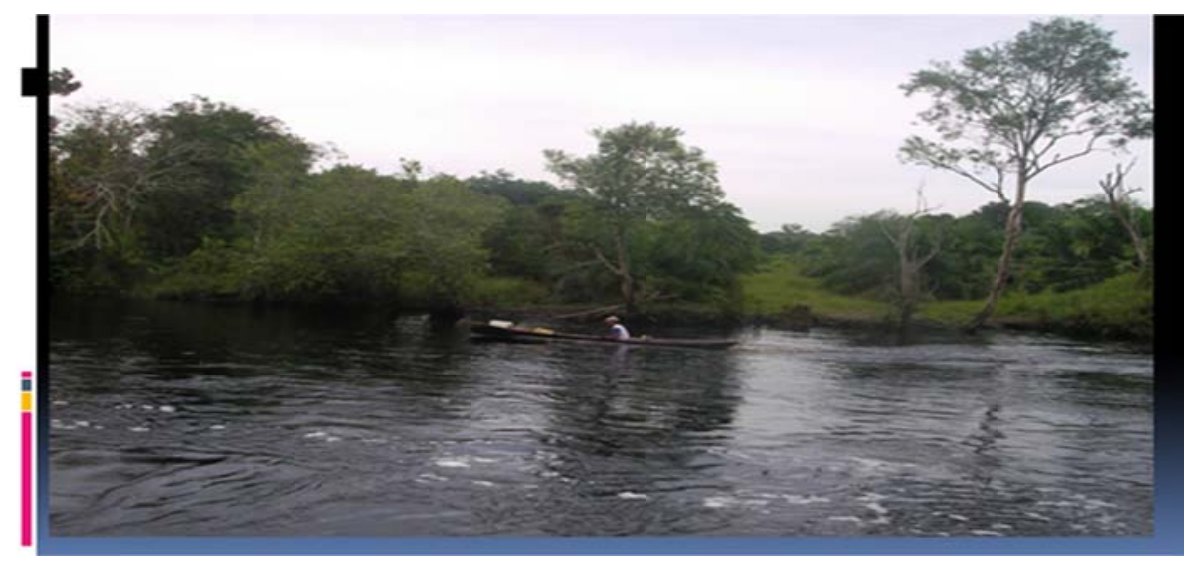

Gambar 4

Sungai Kubu di Kawasan Tanah Adat Sumber Penghidupan 
Jika anak negeri atau masyarakat adat hanya mengambil hasil hutan simpanan sebatas kepentingan minum-makan atau kepentingan pribadi keluarga, maka pemangku adat tidak memungut apa-apa. Jika pengambilan itu sudah digunakan untuk diperjual-belikan, maka lembaga adat memungut pancungalas sebanyak sepuluh satu, maksudnya, kalau diambil 10 maka 1 diserahkan kepada lembaga adat. Jadi nilai pungutan itu sebesar 10\%. Kawasan Hutan Melayupungutan sepuluh satu juga berlaku terhadap hasil laut seperti berbagai jenis kerang. Sedangkan terhadap sarang burung layang-layang berlaku sepuluh limaatau 50\%, yakni dari 10 yang diambil 5 diserahkan kepada lembaga adat yang mengawali kekayaan masyarakat adat ini.

Tanah kebun dan ladang pada tanah adat merupakan tanah produksi yakni tanah untuk menghasilkan berbagai jenis bahan makanan yang dapat dijual. Orang Melayu Melayutelah lama mengenal berkebun lada, kelapa, getah, gambir, tembakau dan cengkeh. Sedangkan di tanah peladangan mereka padi, jagung, labu, dan berbagai sayuran.

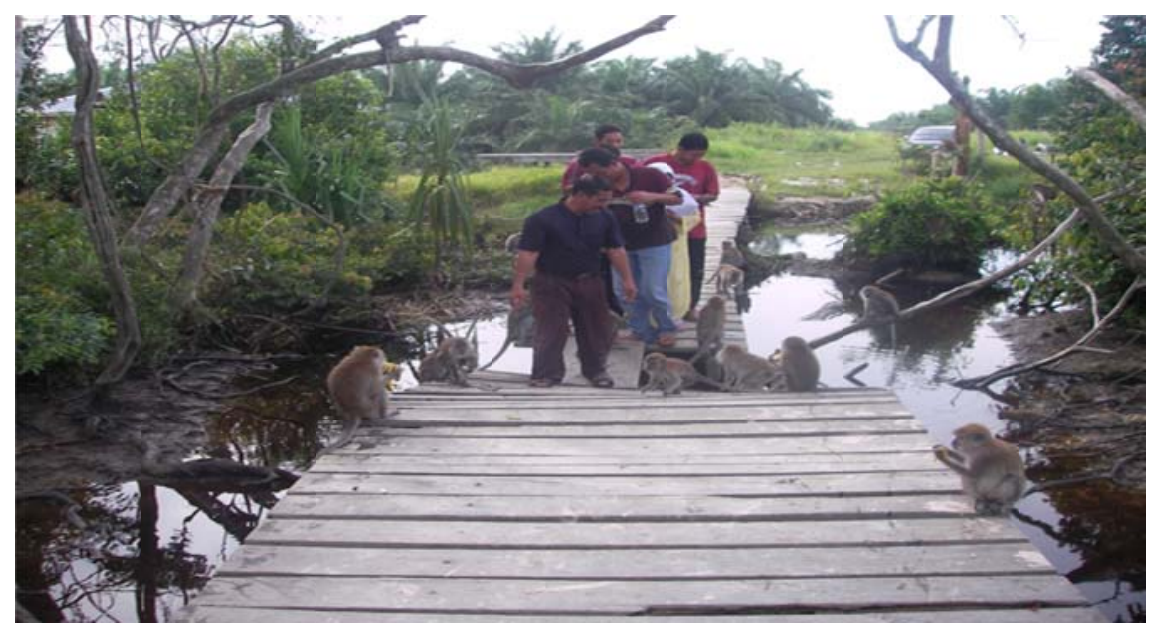

Gambar 5

Kawasan Hutan Tanah Adat di Kubu,Rohil

Rimba Kepungan Sialang adalah gugusan hutan yang bisa terdapat sebagai batas ladang dan kebun, batas perkampungan, atau gugus-gugus hutan sepanjang tebing sungai. Gugus hutan ini dibiarkan menjadi tempat lebah hutan bersarang. Lebah hutan disebut juga sialang, sehingga kayu apa saja yang dijadikannya tempat bersarang disebut kayu sialang. Madu lebah sialang diambil oleh tukang panjat yang di sebut kemantan. Hasil madu lebah ini sebanyak dua bagian untuk tukang panjat, dua bagian lagi untuk warga pesukuan dimana pohon sialang itu berada, sedangkan satu bagian lagi untuk pemangku adat atau orang patut negeri.

Orang Melayumemanfaatkanmadu dua kali dalam setahun. Datangnya musim buahbuahan memberikan keuntungan yang besar bagi mereka. Pada awal pertahunan mereka akan memperoleh madu yang merupakan hasil penyerbukan dari lebah pada bungabunga calon buah dan pada akhir tahun mereka akan mendapatkan hasil berupa 
buah-buahan. Madu yang dihasillkan pada pohon sialang ini mempunyai kualitas tinggi. Madu tersebut dikonsumsi rumah tangga orang Melayudan dijual pada masyarakat desa. Harga madu mencapai Rp 100.000 per botol aqua besar atau \pm 2 liter (harga pada saat penelitian dilakukan).

Lebahbiasanya memilih pohon-pohon tertentu untuk membuat sarang. Pohon-pohon yang biasanya dihinggapi saranglebah disebut pohon sialang. Orang Melayumengenal beberapa jenis pohon sialang antara lain pohon siding, kedundung, pohon kayan kawon, pohon pari, pohon kayu ara, pohon pulai, pohon ipuh, dan pohon sangkuang. Pohon-pohon sialang ini memiliki ukuran yang besar dengan ketinggian \pm 50 meter atau bahkan lebih.

Kepemilikan pohon sialang merupakan warisan secara turun temurun. Dimana hak pengambilan madudiperoleh dari rerayo kepada anak dan selanjutnya. Pohon-pohon sialang milik salah satu anggota Orang Melayuditandai dengan membersihkan pohon-pohon di sekitar pohon tersebut. Apabila tidak dibersihkan maka lebah enggan untuk bersarang. Dalam mengambil madu, Orang Melayumempunyai cara tersendiri. Pada saat penelitian, peneliti sempat diajak Khalifah Mak Nur (58 tahun) untuk melihat prosesi pengambilan maduyang dilakukan Suku Rao di Kubu.

Adapun proses pengambilan maduantara lain sebagai berikut :

1. Memindahkan Penunggu Sialang Memindahkan Penunggu Madu adalah cara memindahkan hantu yang menghuni pohon sialang. Orang Melayupercaya bahwa antu kayan merupakan penjaga pohon sialang. Dalam proses ini mereka membaca jempijempi (mantra-mantra) sebagai berikut:

"Bukan menyito anting aku punyo anting.Bukan menyito dahan aku punyo
dahan.Bukan menyito umpun aku punyo umpun.Bukan menyito batang aku punyo batang.Bukan menyito daun aku punyo daun.Bukan menyito paang aku punyo paang.Bukan menyito madu aku punyo madu.Allah humma sholli ala syaidina Muhammad.Wa Ala Alihi syaidina Muhammad 7 X. Bokat Kabul la llaha Illallah ...

(Wawancara dengan Datuk Mak Noor, di Kubu Agustus 2014)

Orang yang memanjat pohon sialang membawa lantak tersebut disusun rapi didalam tekuluk. Orang Melayumemanjat pohon sialang menggunakan lantak.Lantak biasanya terbuat dari kayu yang merupakan kayu yang strukturnya keras dan mempunyai daya tahan lama. Lantak dipasang dengan cara dipaku ke batang menggunakan penokok. Pada saat melantak mereka membaca:

"Assalamualaikum... membaca selawat, ayat kursi dan surat Al-Ikhlas. Pada masa lalu mereka membaca mantera-mantera yang penuh dengan sihir dan khurafat.

Satu demi satu lantak dipasang sampai pada dahan terakhir dimana sarang lebah telah berada. Mereka selalu melafalkan doa tersebut, karena mereka percaya dengan melafalkan doa tersebut mereka terhindar dari musibah seperti jatuh dari pohon.Orang Melayumenggunakan suluh (obor) untuk mengusir lebah dari sarang. Mereka membakar suluh dan mengasapisarang sehingga lebah pergi menjauh dari sarang. Madu diambil langsung dengan sarang sekalian. Mereka melakukannya dengan tangan kemudian dimasukkan kedalam wadah yang terbuat dari kulit pohon gaharu yang disebut seludung. Nurun manih,seperti 
Husni Thamrin, Zulfan Saam; ECO-Religio-Culture Suatu Alternatif Pengelolaan Lingkungan

halnya memanjat mereka turun melalui lantak/tangga yang telah terpasang.

Pengambilan madu tidak dilakukan oleh orang sembarangan. Mereka yang dapat melakukannya adalah orang-orang pilihan. Senada yang disampaikan oleh Tongkat Nasir dibawah ini:

"ngambil madu tidak bisa dilakukan orang biasa. Yang mengambil adalah orang pilihan. Orang yang boleh menorah pohon sialang".

Mereka yang mengambil madu adalah mereka yang diperbolehkan menoreh pohon sialang tersebut. Pohon sialang sangat dijaga keberadaannya. Bagi mereka yang tidak memiliki pohon sialang, mereka tidak diperbolehkan menoreh bahkan menebang pohon tersebut. Hal ini akan dikenakan sanksi berupa denda adat. Mereka pemiliknya yang hanya dapat mengeksploitasi pohon tersebut. Dalam artian hal ini bertujuan agar tidak terjadinya perebutan didalam pemanenan hasil madu.

Dalam hutan tanah adat dalam penuturan informan Arsyad (67), rotan merupakan hasil hutan yang banyak dimanfaatkan orang Rokan Hilir. Ada bermacam penamaan rotan yang diberikan oleh orang Melayuyang dibuat berdasarkan fungsi serta ukuran rotan tersebut. Penyebutan tersebut antara laindahanang, tobu, manau, rumbai, simambu, balam, getah, lidi dan dahanan. Orang Melayu memanfaatkan rotan selain digunakan untuk membuat peralatan rumah tangga juga dijual guna memenuhi kebutuhan ekonomi mereka sehari-hari. Rotan digunakan untuk membuat peralatan-peralatan yang digunakan seharihari seperti ambung, bakul, tikar, penyalaian, sanggai, dan lukah, serta digunakan untuk pengikattali dalam membuat susudung dan lain sebagainya.
Rotan dahanan (daemonorops) merupakan rotan yang mempunyai harga jual yang tinggi. Rotan ini menghasilkan getah berwarna merah hati yang menempel pada kulit buah rotan yang masih muda. Dalam dunia industri getah ini disebut "dragon blood" karena warnanya mirip dengan darah.Getah dahanandigunakan untuk bahan pewarna, bahan baku obat-obatan (Cina dan Eropa), campuran bahan kosmetik, dan bahan pewarna porselen. Pada masyarakat Dayak, getah dahanang ini digunakan untuk membuat tato, pewarna alat-alat perang dan pewarna baju.

Orang Melayumengambil buah rotan dahanan dengan cara memanjat pohonpohon yang tumbuh di samping rotan dahanan atau dengan cara menarik rotan tersebut kemudian memetik buah-buah muda rotan dahanan. Dalam mengambil buah dahanang mereka hanya menggunakan parang dan ambung sebagai wadah buah dahanang. Buah-buah dahanan yang berwarna merahlah yang mereka ambil karena banyak mengandung getah.

Orang Melayujuga mengumpulkan rotan dahanan dan rotan tebu untuk dijual. Berdasarkan keterangan dari beberapa informan, mereka menjual rotan manau $\mathrm{Rp}$ 50.000/batang dan Rp 15.000/batang untuk rotan tebu. Rotan manau dan rotan tebu yang dijual berukuran panjang antara 3-4 meter. Orang Melayumengambil rotan manau dan rotan tebu dengan cara memotong rotan tersebut dari pangkalnya kemudian menariknya. Sambil menarik mereka menyiangi duri-duri yang melekat pada ruasruas rotan tersebut. Pengambilan rotan ini tidak dilakukan dengan cara mengambil rotan yang mereka jumpai saja, melainkan mereka mengambil rotan yang telah pantas atau sesuai dengan ukuran yang ditetapkan untuk diambil. Seperti yang dikatakan oleh Soleh (62 tahun): 
"Rotan bulih diambik panjangnyo limo boleh potong, kalau indak tak bulih diambik"

Pada era tahun 1970-an dalam penuturan informan M.Nur (67 tahun) rotan yang boleh diambil adalah rotan yang berukuran lima belas potong atau sampai dengan 2,5 meter. Aturan pengambilan rotan tersebut masih ditaati sebagian orang adat Orang Rokan Hilir. Saat ini banyak juga aturan ini tidak ditaati orang Rokan Hilir. Seperti halnya mereka mengambil rotan yang hanya mencapai 7 sampai 10 potong. Hal ini dikarenakan makin sulitnya ditemui rotan yang mencapai ukuran 15 potong tersebut. Kebutuhan ekonomilah yang menyebabkan beberapa Orang Melayu tidak mempertahankan kearifan lokal yang mereka pertahankan selama ini. Selain itu juga, mereka telah mengenal budaya konsumtif.

Dalam penuturan informan Ahmad Poal (73 tahun) sedangkan untuk rotan lidi diambil dengan cara menarik dengan dililitkan pada dua buah kayu yang berukuran kecil. Tujuannya agar duri-duri rotan lidi tersebut dapat terlepas pada saat ditarik. Hal ini dilakukan mengingat rotan lidi berukuran kecil dan juga untuk meminimalisir tenaga yang keluar. Cara ini merupakan cara yang paling efektif utnuk mengambil jenis rotan lidi. Rotan lidi selain untuk dijual dipasar juga digunakan untuk membuat peralatan yang dibutuhkan dan digunakan sehari-hari. Orang Melayumengangkut rotan lidi dengan cara menggulung rotan tersebut seperti halnya menggulung tali. Gulungan tersebut dibawa dengan cara menggendong yang dilakukan pada punggung.

Selain rotan dalam penuturan informan Ali (65) di Sei Majo di Kubu, Orang Melayujuga memanfaatkan getah pohon damar (Aghatis sp). Getah pohon damar pada masa lalunya digunakan sebagai alat penerangan dimalam hari. Pada masa lalu damar merupakan alatpenerangan yang turun temurun dipakai dan diwariskan dari generasi ke generasi. Pada saat ini penggunaan damar sudah tidak ada lagi. Umumnya masyarakat desa tersebut memakai minyak tanah untuk lentera dan menggunakan mesin diesel yang berbahan bakar premium/bensin. Orang Melayuhanya menggunakan premium/bensin sebagai bahan bakar sepeda motor yang kebanyakan dari mereka telah memiliki alat transportasi ini.

Orang Melayumengambil damar dengan cara menoreh pohon damar. Pohon tersebut akan mengeluarkan getah yang berbentuk kekristalan. Kemudian damar ini dibungkus dengan kulit kayu yang berbentuk seperti obor.Damar ini memiliki daya tahan lama, sedangkan Orang Melayudapat melakukan aktiftas dimalam hari sebelum berangkat tidur. Kulit pohon meranti (shorea sp) dimanfaatkan Orang Melayusebagai bahan baku lantai sebuah bangunan, seperti balai lantai bangunan mereka.

Dalam penuturan informan M.Noor (57 tahun) dahulu berbagai jenis tumbuhan obatobatan dapat dapat ditemui dalam tanah adat di Rokan Hilir. Tumbuhan obat yang digunakan Orang Melayuternyata memiliki mutu dan kualitas tinggi. Hanya saja dalam pemanfaatan tumbuhan obat dilakukan dengan cara tradisional.

Para dukun meracik dan meramu tumbuhan obat-obatan untuk mengobati berbagai jenis penyakit sesuai dengan pengetahuan mereka tentang tumbuhan obat tersebut. Seorang dukun Ketah (73 tahun) mengidentifikasi jenis penyakit yang menyerang seseorang dan mencari tumbuhan obat yang sesuai untuk penyakit tersebut.Tumbuhan obat-obatan ini dapat mereka temukan disekitar kawasan hutan adat. Pengetahuan tentang ekosistem hutan sebagai dasar yang digunakan dalam 
Husni Thamrin, Zulfan Saam; ECO-Religio-Culture Suatu Alternatif Pengelolaan Lingkungan

menemukan tumbuhan obat-obatan tersebut. Misalnya suatu jenis tumbuhan obat yang hanya tumbuh didaerah-daerah tertentu saja. Hal ini memudahkan dalam memperolehnya.

Tabel 2

Beberapa Contoh Tumbuhan Obat-obatan

\begin{tabular}{|l|l|l|l|l|}
\hline No & \multicolumn{1}{|c|}{ Tumbuhan } & \multicolumn{1}{|c|}{ Khasiat } & \multicolumn{1}{|c|}{ Bagian } & \multicolumn{1}{|c|}{ Proses Pembuatan } \\
\hline 1 & Benalu & Anti kanker & Tangkai & $\begin{array}{l}\text { direbus kemudian } \\
\text { diminum }\end{array}$ \\
\hline 2 & Labu hutan & Obat cacing pita & Biji & $\begin{array}{l}\text { Biji direbus airnya } \\
\text { diminum }\end{array}$ \\
\hline 3 & $\begin{array}{l}\text { Keduduk } \\
\text { (Gironiera } \\
\text { nervos planch) }\end{array}$ & Obat berak darah & Daun & $\begin{array}{l}\text { Daun direbus dan } \\
\text { rebusan daun } \\
\text { tersebut diminum }\end{array}$ \\
\hline 4 & $\begin{array}{l}\text { Kedundung } \\
\text { hutan (sentiria } \\
\text { laevgata BL) }\end{array}$ & Obat wanita setelah melahirkan & Akar & $\begin{array}{l}\text { Akar direbus lalu } \\
\text { diminum }\end{array}$ \\
\hline 5 & Sedinginan & Demam ,sakit kepala & Daun & Diremas pada badan \\
\hline 6 & $\begin{array}{l}\text { Selotup } \\
\text { Daun,batang }\end{array}$ & $\begin{array}{l}\text { Direbus airnya } \\
\text { diminum }\end{array}$ \\
\hline 7 & Sambung ura & Obat luka & Daun & $\begin{array}{l}\text { Daun diremas hingga } \\
\text { berair diteteskan } \\
\text { pada luka }\end{array}$ \\
\hline 8 & Kasa kasa & Obat batuk,sakit kepala, demam & Akar & $\begin{array}{l}\text { Daun direbus, lalu } \\
\text { diminum . }\end{array}$ \\
\hline
\end{tabular}

Sumber : Observasi Lapangan, 2014

Demikianlah pemangku adat Melayu memelihara kekayaan alamnya sehingga masyarakat adat dapat mengurus kepentingan dirinya sendiri, tidak tergantung kepada pihak manapun juga. Pemangku adat ini memang layak dijuluki orang arif bijaksana karena dia pandai mengira dan membagikan, tahu membaca kias dan sindiran. Untuk keperluan hayat hidup, mereka dapat mengolah kebun dan ladang serta mengambil hasil-hasil hutan dan laut. Dari pancung alasdan hasil darat, sungai dan laut dapat memperoleh dana untuk memelihara lembaga adat serta membangun kepentingan bersama. Dari pungutan hasil darat, sungai,
Berbagai jenis tumbuhan obat yang biasa dimanfaatkan Orang Melayudapat dilihat pada tabel di bawah ini: 
adalah milik bersama masyarakat adat. Kepemilikan itu bisa bertingkat. Ada yang memiliki bersama satu pesukuan, ada pula milik bersama satu kesatuan masyarakat adat. Tanah milik bersama pada tingkat pesukuan dan kesatuan masyarakat adat hanya punya hak pakai. Tanah simpanan adalah milik bersama masyarakat adat. Sementara kebun dan ladang bisa menjadi milik persukuan.Tanah pekarangan, sebagian milik bersama suatu pesukuan, sebagian lagi (yang berasal dari tanah kebun dan ladang) merupakan tanah milik persukuan.

Luas satu unit tanah simpanan sejauh bunyi gong (setengah hari berjalan kaki) yakni sekitar $10 \mathrm{~km}$ persegi. Luas satu unit ladang, kebun dan pekarangan sejauh bunyi ayam berkokok, yaitu kira-kira 500 meter persegi. Sedangkan luas tanah kepungan sialang sejauh murai berkicau, ditaksir 100 sampai 200 meter persegi. Orang Melayu Melayutelah menentukan batas hutan tanah untuk tiap kepala pesukuandalam masyarakat adat. Orang Melayu Melayutelah menentukan besar kayu yang boleh di jual belikan. Hukum adat Melayujuga memberi denda terhadap perusahaan yang merusak hutan dan memberi hak istimewa untuk orang Melayu untuk memelihara tanah dengan menanam padi dan rumbia.

Sejalan dengan itu para ulama yang disebut juga imam dan khatib, tidak pernah bosan memberi peringatan agar jangan sampai melampaui batas, baik terhadap diri sendiri maupun terhadap masyarakat dan alam. Orang tersebut disebut juga pelita yang tak kunjung padam, suluhnya menyala di dunia sampai ke akhirat, duduknya bercermin kitab, sedangkan tegaknya selalu rintang oleh petuah. Ini terjadi karena pemandu kehidupan beragama (ulama) itu selalu memberi nasehat, penerangan, petunjuk, dan jalan yang benar kepada siapapun juga, agar memelihara sebaik-baiknya segala macam nikmat Allah yang telah tersebar di muka bumi ini.

Pembagian hutan tanah orang Melayu yang telah dirancang oleh pemangku adat mereka benar-benar telah memberikan kesejahteraan yang alami. Dikatakan demikian, sebab dengan tata hutan tanah serupa itu, bukan hanya sekedar memberikan kesejahteraan bagi makhluk manusia semata, tetapi juga dapat dirasakan oleh margasatwa, serangga dan kayu-kayuan di hutan belantara. Semua makhluk hidup mendapat tempat untuk hidup secara wajar dalam tata ruang masyarakat adat Melayu. Akibatnya dapat dinikmati kehidupan yang alami, bersih, segar dan indah. Di situ dapat didengar kicau murai dan bunyi burung yang silih berganti, ada air yang jernih mengalir sepanjang bebatuan sungai dan pantai. Hutan belantara yang memberikan udara yang sejuk dan nyaman. Inilah keadaan yang benar-benar bisa membuat orang merasa damai dan tenteram karena semuanya itu adalah pancaran dari kasih sayang Tuhan yang bisa menggugah hati untuk memeliharanya baikbaik serta membuka jalan untuk bersyukur dan mengabdi kepada Sang Khalik.

Hutan tanah orang Melayu terpelihara kelestariannya selama teguh memegang hukum adat Rokan Hilir. Kerusakan hutan,flora dan faunanya ini mulai mengalami degradasi sejak era kebijakan pemerintah orde Soeharto (1968-1998). Dalam masa pemerintahan orde itu, dengan memakai dalih pembangunan, maka dibagi-bagilah hutan tanah masyarakat adat di Rokan Hilir, diberikan kepada Hak Penguasa Hutan $(\mathrm{HPH})$, transmigrasi dan berbagai perusahaan besar perkebunan baik milik swasta maupun milik pemerintah. Masyarakat adat yang telah melestarikannya ratusan tahun tidak mendapat imbalan apa-apa. Mereka malah jatuh miskin menjadi buruh pada HPH dan kuli perusahaan perkebunan. 
Pemangku adat Melayu, sebagai cendekiawan masa silam menyadari betul betapa tingkah laku dan perangai manusia jika tidak dikawal dengan adat, niscaya akan mendatangkan bencana. Dengan kata lain, kekuasaan harus tunduk pada hukum adat yang telah lama mengakar dalam masyarakat Rokan Hilir. Oleh karena itu, terhadap pihak petani dan peternak yang bisa berseberangan kepentingannya, pemangku adat Melayu juga telah merancang undang-undang atau ketentuan sehingga menjadi selaras dan saling menguntungkan. Perputaran masa dalam setahun dibagi menjadi dua oleh pemangku adat. Enam bulan pertama diserahkan kepada petani untuk berladang. Dalam masa itu petani mengolah ladang, bertanam, memelihara ladang sampai akhirnya menuai. Pihak peternak mengikat dan mengembalakan ternaknya agar tidak sampai mengganggu ladang.

Giliran enam bulan berikutnya diberikan kepada peternak. Setelah petani selesai menuai, maka ternak besar seperti kambing, sapi dan kerbau dapat dilepaskan di tanah peladangan yang tidak terpakai lagi. Siklus dan perganatian antara kepentingan petani dan peternak ini telah membuat tanah peladang terpelihara kesuburannya, sebab ketika ladang padi selesai dituai, ternak dapat mencari makan di sana. Di lahan itu, ternak merumput, kawin dan membuang kotorannya. Hasilnya, di samping ternak dapat berkembang biak dengan baik, ladang padi juga mendapat pupuk alam dari kotoran ternak.

Masih ada piranti lain untuk mencegah kemalangan yang bisa menimpa ladang. Pertama, pemangku adat membuat ketentuan agar petani turun keladang secara serempak. Untuk itu diadakan upacara turun ke ladang yang di sebut juga doa padang. Dalam upacara ini petani berkumpul (bahkan juga seluruh warga) untuk makan bersama dan berdo'a minta selamat peladangan mereka kepada Tuhan. Kedua, di bentuk organisasi tani untuk mengerjakan ladang yang di sebut tobo. Organisasi ini bekerja secara bergiliran di semua ladang yang di hutan dan sungai sebagai tempat pencarian orang Melayu yang dimiliki oleh anggotanya. Dengan demikian ladang cepat selesai. Dengan cara turun keladang secara bersam-sama ini termasuk cara mengerjakan ladang secara bergiliran dengan tobo, gangguan hama tanaman (pianggang, belalang dan serangga lainnya) serta musuh tanaman (cingkuk, beruk, babi dan gajah) dapat ditanggulangi secara bersama sehingga kerugian peladang dapat dibatasi jika terjadi musibah itu.

Selain itu, untuk memelihara keperluan zat kapur pada sawah (ladang rawang), rupanya ada suatu kebiasaan petani yang sederhana namun amat efektif. Petani terbiasa membiarkan siput sawah berkembang biak dalam sawahnya. Siput dapat menjadi siklus ekosistem pertanian sebagai pengapuran pada tanah dan padi.

Dalam tanah adat orang Melayu disamping digunakan sebagai tempat bertani dan berkebun, pada tanah adat tersebut juga digunakan sebagai tempat berternak. Dalam berternak tersebut kadang kala terjadi terjadi konflik antar satu peternak dengan peternak yang lain.

Pemimpin masyarakat adat Melayu, telah memandang jabatan sebagai jasa untuk dikenang oleh anak cucu di belakang hari. Sebagaimana kata Raja Ali Haji pengarang Riau yang piawai itu dalam ikat gurindamnya, "hendaklah berjasa kepada yang sebangsa". Mereka tidak mau berbuat melampaui batas, apa lagi berbuat aib. Mereka punya perhatian yang besar atas keadaan nasib kaum yang lemah. Dalam hal ini, kita lihat lagi kearifan gagasan mereka. Pemangku adatpun telah membuat pula adat beternak, yang mengatur hubungan antara orang kaya (yang banyak 
mempunyai ternak) dengan pihak yang miskin (tak punya ternak).

Adat beternak itu disebut juga adat mempeduai ternak. Disebut demikian, karena posisi ternak menjadi milik berdua antara yang punya ternak dengan pihak yang memelihara ternak. Kemudian disebut juga mempeduai (menjadi milik berdua) karena hasil keturunan ternak itu akan dibagi dua oleh mereka. Adapun jelasnya adat mempeduai ternak itu ialah:Pihak yang punya ternak disebut induk semang sedangkan yang memelihara ternak disebut anak semang. Ternak yang diserahkan induk semang kepada anak semang disebut pokok sedangkan anak keturunannya di sebut ujung.Jika induk semang terpaksa menyerahkan sepasang ternak (karena anak semang sulit mendapat pejantan) maka yang betina menjadi pokok, sedangkan yang jantan ditaksir harganya ketika itu. Nantinya yang jantan ini setelah dibesarkan oleh anak semang (sambil jadi pejantan) maka ada bagian untuk dia. Bagian anak semang dari yang jantan itu adalah setengah dari harga ternak jantan itu, setelah dikurangi dengan harga semula sewaktu diterima (ditaksir) oleh anak semang.

Jika anak semang amat kesulitan, maka dia dapat menjual seekor pokok (sebelum ada ujung), asal nanti dapat digantinya dengan ujung dari pembagian untuknya.Jika persekutuan akan dibubarkan, maka pokok di kembalikan kepada induk semang, sedangkan ujung dibagi dua oleh mereka berdua.Jika persekutuan berjalan dalam jangka panjang, maka anak dan induk semang dapat menjual ujung bergantian.Jika pokok dari induk semang habis mati atau karena bencana di luar kemampuan anak semang menyelamatkannya, dan induk semang tidak memberi pokok baru, maka pokok yang mati dianggap hilang atau habis. Peduai (persekutuan) dianggap bubar dan anak semang tidak di tuntut apa-apa.Jika induk semang memberi pokok baru dan anak semang menerimanya, maka persekutuan dilanjutkan. Tetapi pokok yang sudah hilang harus diganti kelak oleh anak semang, ketika persekutuan akan dibubarkan.Pokok dapat dipermuda dengan cara induk ternak yang sudah tua yang menjadi ujung itu dapat dijual serta dibagi dua oleh anak semang.Beberapa jangka waktu persekutuan ini terserah kepada kedua belah pihak. Jika salah satu pihak meninggalkan dunia, pihak ahli waris dapat meneruskan atau membubarkan persekutuan.

Sistem budaya masyarakat Melayu mempunyai muatan yang baik untuk mengelola lingkungan dengan gaya yang harmonis. Dalam sistem budaya orang Melayu di Melayubisa terbaca dengan jelas bagaimana nila-nilai budaya mereka memberi pedoman dan arah agar lingkungan terpelihara. Semuanya terkandung dalam berbagai aspek budaya mereka. Peternakan orang Melayu dalamkebun baik secara lisan maupun dalam tindakan perbuatan yang nyata.

Untuk jaminan kehidupan kaum yang sejak dulu hingga sekarang masih terikat pada tanah karena masyarakat bercirikan agraris. Masyarakat daerah Melayupada umumnya petani yang memerlukan tanah untuk kelangsungan hidup sehari-hari. Ini sejalan dengan ungkapan adat :

kalau terpelihara hutan dan tanah, banyak manfaat dapat dirasakan: ada kayu untuk beramu, ada tumbuhan untuk ramuan, ada hewan untuk buruan, ada getah membawa faedah, ada buah membawa berkah, ada rotan penambah penghasilan, kalau terpelihara hutan dan tanah, manfaatnya banyak faedahnya besar, di situ dapat tempat bersandar, di situ dapat tempat berlegar, di situ dapat membuang lapar, di situ adat dapat didengar, di situ kecil menjadi besar, di situ sempit menjadi lebar, apabila rusak alam 
Husni Thamrin, Zulfan Saam; ECO-Religio-Culture Suatu Alternatif Pengelolaan Lingkungan

sekitar, sempit tidak dapat berlegar, goyah tidak dapat bersandar, panas tidak dapat mengekas, hujan tidak dapat berjalan, teduh tidak dapat berkayuh, apabila alam sudah binasa, balak turun celaka tiba, hidup melarat terlunta-lunta, pergi ke laut malang menimpa, pergi kedarat miskin dan papa.

(Wawancara dengan Hasan Basri, di Bangko Pusako, tanggal 7 Agustus 2012)

Dalam masyarakat RokanHilir semua tanah memiliki manfaat ekonomi. Tidak ada sebidang tanahpun yang dipandang tidak memiliki kegunaan karena masyarakatnya adalah agraris bahwa semua tempat dan jenis tanah semuanya mempunyai fungsinya masing-masing dan dapat dimanfaatkan.

Hak adat merupakan hak persekutuan (komunitas) atas tanah, sedangkan pelaksanaannya dilakukan oleh Datuk sebagai pemimpin suku. Hak persekutuan dengan hak individu ada hubungan dua timbal balik yang saling mengisi. Semakin kuat pengawasan dan penguasaan persekutuan secara komunal terhadap hak adat, penguasaan individu atas tanah semakin melemah. Tetapi apabila semakin kuat penguasaan individu menguasai tanah, hak adat persekutuan semakin berkurang terhadap tanah.

Anggota persekutuan hukum adat mempunyai hak yang sama untuk memanfaatkan hak-hak adat yang terdapat dikawasannya. Hak yang dipunyai oleh individu persekutuan di antaranya adalah (1) membuka tanah atau meneroka dan mengusahakan tanah secara terus menerus; (2) mengumpulkan hasil-hasil hutan seperti, kayu, rotan, dan damar; (3) berburu binatang liar yang hidup di kawasan wilayah persekutuan; (4) mengambil hasil dari pohonpohon yang tumbuh liar; dan (5) mengusahakan untuk dibina suatu kolam ikan (Laretna,2009).
Hak adat pada dasarnya mempunyai fungsi yang cukup luas, karena memberikan berbagai hak kepada anggota persekutuan hukum diantaranya (1) hak menggunakan tanah sebagai tempat tinggal; (2) menggunakan tanah sebagai kawasan pertanian dan mengumpulkan hasil hutan; (3) menggunakan tanah sebagai tempat menggembalakan ternak dalam kawasan tanah adat; (4) berburu atau menangkap ikan (Vollen Hoven (1930).

Mengenai sifatnya tanah adat diantaranya (1) hak adat hanya dapat berada dalam pemilikan masyarakat dan tidak pada orang tertentu; (2) hak adat tidak dapat dipindah pemilikannya tanpa seizin daripada ketua adat; dan (3) jika hak itu dilepaskan untuk sementara waktu bila ada orang lain di luar persekutuan hukum adat, ia harus membayar ganti kerugian tentang penghasilan yang hilang ( Harsono,2000).

Berbagai hak yang diperoleh anggota masyarakat persekutuan terhadap hak adat itu menujukkan adanya hubungan hukum antara individu dengan objek hak adat, terutama dengan yang diusahakannya. Jadi, anggota persekutuan berhak membuka tanah baru. Tanah yang diusahakan untuk ditanami berbagai jenis tanaman menjadi hak miliknya. Apabila kemudian tanah itu dibiarkan dan tidak dikerjakan, hubungan hukum antara warga adatdengan tanah hak kepemilikannya menjadi hapus, sehingga hak perorangan menjadi hilang dan kembali kepada hak persekutuan untuk menguasai tanah adat tersebut.

Menurut Harun Datuk Batrem (73 tahun) Datuk di daerah Bangko RokanHilir menyatakan:

"keberadaan tanah adat dalam lingkungan masyarakat daerah RokanHilir mengalami perubahan pemilikan dan pemanfaatan. Tanah adat sebagai milik bersama anggota masyarakat persekutuan 
hukum adat dari hari ke hari mengalami pengurangan, karena pengaturan tanah adat secara hukum adat tidak dilakukan lagi. Tanah-tanah adat pengaturannya telah diambil alih oleh pemerintah. Banyak tanah adat izinnya diberikan kepada perusahaan seperti Caltex, perusahaan kelapa sawit, penanaman akasia secara massal. Sekarang tanah-tanah di Melayusebagian besar di kuasai oleh pendatang. Orang Melayugila mau jual tanah, sedang pendatang gila mau beli tanah, maka habislah tanah adat di Rokan Hilir. Akibat dari berbagai sektor orang Melayumengalami kesusahan "

Oleh karena pemanfaatan oleh individuindividu persekutuan juga karena bertambahnya jumlah penduduk. Berbagai teori telah diajukan dalam usaha menganalisis hubungan antara kepadatan penduduk dan pemanfaatan tanah oleh manusia. Tetapi sebuah teori yang dapat menguraikan perubahan yang kini terjadi di daerah padat di dunia dan sekaligus memberikan gambaran mengenai masa depan, sukar ditemukan. Menurut Boserup (1965) di masa lampau pertumbuhan penduduk dalam sebuah masyarakat mengakibatkan intensifikasi penggunaan tanah. Pandangan ini tercermin pada keyakinan beberapa kalangan (World Bank 1982: 93) bahwa penggunaan teknologi yang tepat akan meningkatkan produktivitas tanah sehingga pada akhirnya kemiskinan di desa dapat dikurangi. Apabila distribusi penguasaan atas tanah yang lebih merata akan meningkatkan standar kehidupan orang miskin (Gilbert, 1996; Lewis , 1966; dan Smith, 1979), akan tetapi pemerataan ini tidak akan menjamin kehidupan yang lebih baik bila sumber tanahnya terbatas.

Tanah adat yang semula sangat luas akhirnya tinggal sedikit. Hal ini disebabkan penguasaan tanah adat tanpa terkendali oleh berbagai pihak seperti pemerintah, dan pihak swasta. Akibatnya tanah adat yang seharusnya dapat dimanfaatkan oleh anggota persekutuan telah diambil sebagiannya oleh anggota masyarakat di luar persekutuan. Adapun yang memanfaatkan tanah adat pada masa sekarang diantaranya adalah Pemerintah Daerah, Dinas Kehutanan, pihak swasta, pejabat desa (kampung), penghulu adat dan warga masyarakat luar.Dari fakta lapangan yang didapati, warga masyarakat persekutuan hukum adat yang paling sedikit memanfaatkan tanah adat tersebut.

Sistem pengelolaan dan pemanfaatan tanah adat biasanya dilakukan secara kolektif. Setiap orang mengusahakan tanah untuk ditanam berbagai jenis tanaman sesuai dengan keadaan tanah itu sendiri. Ada sebagian anak-kemanakan yang mengelola dan memanfaatkan tanah adat dengan cara melakukan kerjasama dengan membentuk kelompok tani yang anggotanya terdiri dari anggota kerabat dekat. Sistem kerja kelompok ini bergantian diantara anggota-anggota kelompok mula dari menanam sampai mengambil hasil pertanian.

Pengelolaan tanah pertanian dengan sistem kelompok ini sangat menguntungkan, karena dengan kerja secara berkelompok dapat diusahakan berbagai jenis pekerjaan. Dari pekerjaan yang ringan sampai pada pekerjaan yang berat. Bekerja secara kelompok juga memberikan manfaat dari segi waktu karena pekerjaan dapat diselesaikan dalam waktu tidak terlalu lama. Anggota kelompok juga dapat berbagi pengalaman dalam sistem pengelolaan tanah serta sistem pertanian, sehingga masing-masing anggota dapat menambah ilmu pengetahuan tentang pertanian.

Menurut ketentuan hukum adat di daerah Melayutanah merupakan milik komunitas adat, setiap anggota komunitas mempunyai kewajiban dan hak yang sama untuk memanfaatkan tanah adat. Akan tetapi untuk mewujudkan kebersamaan kewajiban 
Husni Thamrin, Zulfan Saam; ECO-Religio-Culture Suatu Alternatif Pengelolaan Lingkungan

dan hak bagi semua anggota masyarakat adat adalah suatu hal yang sangat sukar. Oleh karena masing-masing individu mempunyai kemauan dan pandangan yang berbeda. Demikian juga halnya dalam melakukan pengelolaan tanah adat tersebut.Untuk mengatasi perbedaanperbedaan serta mewujudkan suatu sikap dan pandangan sama, hukum adat memberi kuasa kepada penghulu sebagai ketua suku untuk mengelola tanah adat.

\section{Eco-Religio-Culture dan Kearifan Lokal}

Masyarakat Melayu sangat banyak mempunyai nilai-nilai kearifan lingkungan menyangkut aspek ekologis, religiu, sosial, ekonomi dan budaya. Aspek-aspek kearifan lokal ini sudah lama tertanam dalam masyarakat Melayu sehingga mampu mempertahankan keberlangsungan hidup Rokan Hilir. Peneliti melalui pengamatan lapangan dapat mengiventarisir aspek-aspek kearifan lingkungan masyarakat Melayuyang dapat di lihat pada Tabel 3.
Masyarakat Melayumengenal berbagai bentuk kearifan lokal. Aspek kearifan lokal aspek ekologis,sosial ekonomi dan sosial budaya. Aspek ekologis menyangkut sub aspek (1) Tanah,(2) Pemeliharaan hutan,(3) Pemeliharaan sungai, laut dan danau, dan (4) Flora dan Fauna. Aspek Sosial ekonomi meliputi sub aspek(1) Bertani, (2) Berladang, (3) Nelayan, (4)Barang Larangan, Pancung Alas, dan Tapak Lawang. Aspek Sosial Budaya meliputi sub aspek (1) Nilai-nilai adat, (2) Hukum Adat,(3).Pranata adat, dan (4) Sistem teknologi tradisional.

Beberapa jenis hutan-tanah adat yang merupakan kearifan lokal masyarakat Melayu yang disebut diatas ditujukan untuk fungsi ekologis. Klasifikasi lingkungan ini merupakan bentuk rotasi pemanfaatan dan pengelolaan sumber daya kearifan lokal. Misalnya sistem penggunaan lahan ini dimaksudkan agar penggunaan tanah adat di dalam hutan secara berurutan dapat menjadi sumber daya sampinga

Tabel 3

Aspek-Aspek Kearifan Lokal Rokan Hilir

\begin{tabular}{|l|l|l|l|}
\hline No & $\begin{array}{c}\text { Aspek } \\
\text { Kearifan } \\
\text { Lokal }\end{array}$ & Sub Aspek & \multicolumn{1}{|c|}{ Bentuk/Contoh } \\
\hline 1 & Ekologis & 1. Tanah & 1. Tunjuk ajar pemeliharaan tanah \\
& & & 2. Tanah millik persukuan \\
& & 3. Hubungan manusia dengan tanah sakral \\
& & 4. Tanah sebagai identitas \\
& & 5. Tanah sebagai simbol status \\
& & 6. Tanah sebagai geneologi \\
& & 7. Mitos-mitos tentang tanah \\
& & & 8. Upacara selamatan tanah \\
& & & 9. Tanah mempunyai nilai supranatural \\
& & 10. Aturan-aturan adat tentang tanah \\
& & 11. Dokumen tanah adat \\
\hline
\end{tabular}




\begin{tabular}{|c|c|c|c|}
\hline & & $\begin{array}{l}\text { 2. Pemeliharaan } \\
\text { Hutan }\end{array}$ & $\begin{array}{l}\text { 1. Petuah menjaga hutan } \\
\text { 2. Tata ruang tradisional hutan adat } \\
\text { 3. Hutan yang dilestarikan di pinggir sungai } \\
\text { 4. Hutan adat tempat keramat yang dihuni makhluk halus (Sekodi) } \\
\text { 5. Hutan garapan (untuk penghidupan) } \\
\text { 6. Pantang larang menebang hutan } \\
\text { 7. Hutan kerajaan bunyian } \\
\text { 8. upacara semah membuka hutan (menotou hutan) } \\
\text { 9. Petuah, mitos, magis, dan doa bersialang } \\
\text { 10. Pohon sialang milik persukuan } \\
\text { 11. Pohon sialang tidak boleh ditebang }\end{array}$ \\
\hline & & $\begin{array}{l}\text { 3. Pemeliharaan } \\
\text { Sungai, Laut } \\
\text { dan Danau }\end{array}$ & $\begin{array}{l}\text { 1. Petuah menjaga laut dan sungai } \\
\text { 2. Sumber air untuk kebutuhan ritual dari hutan keramat atau } \\
\text { kuburan keramat } \\
\text { 3. Sumber air yang telah dijampi oleh dukun atau guru tarekat } \\
\text { untuk berkat atau pengobatan } \\
\text { 4. Ada penunggu sungai, laut dan selat } \\
\text { 5. Upacara semah, tepuk tepung tawar menjaga sungai, laut dan } \\
\text { selat } \\
\text { 6. Pengonghih (pengerih) yang terdiri dari jala, solong, dan } \\
\text { penganak terbuat dari bambu dan rotan diberi pelampung dari } \\
\text { kayu } \\
\text { 7. Anggau (jaring pendek pada perahu), langgai (jaring berbentuk } \\
\text { tangguk) } \\
\text { 8. Lukah, pengilar (lukah guling), tengkalak }\end{array}$ \\
\hline & & $\begin{array}{l}\text { 4. Flora dan } \\
\text { Fauna }\end{array}$ & $\begin{array}{l}\text { 1. Pantang menebang kayu berbuah } \\
\text { 2. Pantang menebang kayu bergetah merah } \\
\text { 3. Panang menebang kayu agho } \\
\text { 4. Pantang menangkap harimau, gajah, ular penunggu, buaya } \\
\text { 5uth, limbek putih } \\
\text { 5. Pantang menebang kayu sialang } \\
\text { 6. Pantang merusak tumbuh-tumbuhan obat } \\
\text { 7. Kepunahan flora-fauna langka }\end{array}$ \\
\hline 2. & $\begin{array}{l}\text { Sosial- } \\
\text { Ekonomi }\end{array}$ & $\begin{array}{l}\text { 1.Bertani dan } \\
\text { Berladang }\end{array}$ & $\begin{array}{ll}\text { 1. Upacara tepung tawar berladang } \\
\text { 2. Betobo } \\
\text { 3. Pantang ladang dan kebun } \\
\text { 4. Petuah, mantera, mitos berladang dan berkebun } \\
\text { 5. Sakralisasi terhadap padi (puti soi gambolo soi) } \\
\text { 6. Berladang tidak boleh secara individu } \\
\text { 7. Doa bersama ketika panen padi } \\
\text { 8. Hasil panen dibagi bersama } \\
\text { 9. Hasil panen diberikan pada penunggu ladang } \\
\text { 10. Hasil panen diberi kepada kepala suku tongkat dan induk }\end{array}$ \\
\hline & & 2. Nelayan & $\begin{array}{l}\text { 1. Upacara tepung tawar turun ke laut } \\
\text { 2. Tidak boleh takabur pergi ke laut } \\
\text { 3. Mitos, magis, mantra, doa-doa ke laut } \\
\text { 4. Tidak boleh menangkap ikan lumba-lumba, paus, dan duyung } \\
\text { 5. Pukat adalah jaring yang terbuat dari benang kasar atau tali } \\
\text { halus yang disamak dengan tannin } \\
\text { 6. Jaring } \\
\text { 7. Jala } \\
\text { 8. Serambang alat penikam ikan } \\
\text { 9. Tempuling hampir sama dengan serampangan tetapi matanya } \\
\text { diberi tali, panjang dan gagangnya dapat dilepaskan } \\
\text { 10. Tangkul jaring empat persegi } \\
\text { 11. Belat terbuat dari bambu dijalin dengan rotan untuk menangkap } \\
\text { udang }\end{array}$ \\
\hline & & $\begin{array}{l}\text { 3.Barang } \\
\text { Larangan, } \\
\text { Pancung Alas } \\
\text { dan Tapak } \\
\text { Lawang }\end{array}$ & $\begin{array}{l}\text { 1. Pancung alas hasil bagi hutan bagi orang luar } 10 \% \text { untuk } \\
\text { masyarakat adat } \\
\text { 2. Tapak lawang bagi hasil pertanian } 10 \text { gantang perkebun (10 } \\
\text { kati) luas ladang } \\
\text { 3. Barang larangan (gading gajah, geligo, gaharu) tidak boleh } \\
\text { diganggu gugat kecuali izin Sultan Siak }\end{array}$ \\
\hline
\end{tabular}




\begin{tabular}{|c|c|c|c|}
\hline \multirow[t]{4}{*}{3} & \multirow[t]{4}{*}{$\begin{array}{l}\text { Sosial } \\
\text { Budaya }\end{array}$} & 1.Nilai-nilai Adat & $\begin{array}{l}\text { 1. Petuan, kepercayaan, sastra dan pantang larang } \\
\text { 2. Pemilihan tapak rumah tidak mengganggu urat bumi (ditentukan } \\
\text { oleh pawang) } \\
\text { 3. Upacara pulih tanah (tanah dianggap bagaikan orang sakit) doa- } \\
\text { doa } \\
\text { 4. Kayu yang dilarang membuat rumah: kayu merbau berdarah } \\
\text { (penunggu bumi), mata kayu (biyadi) } \\
\text { 5. Upacara pendirian rumah ditepung tawari } \\
\text { 6. Rumah dibuat bertangga lima atau tujuh } \\
\text { 7. Pintu rumah ibu, pintu rumah tengah, pintu rumah dapur, tidak } \\
\text { boleh dibuat sejajar untuk menyekat muhrim dan non muhrim }\end{array}$ \\
\hline & & 2. Hukum Adat & 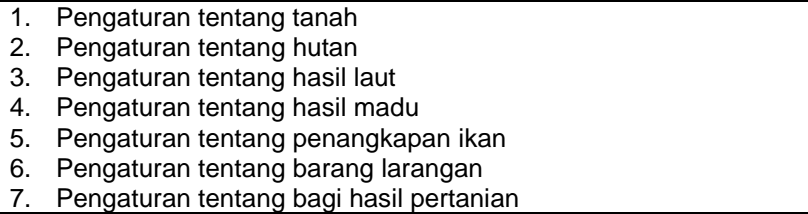 \\
\hline & & 3.Pranata Adat & $\begin{array}{ll}\text { 1. } & \text { Struktur pemerintahan adat } \\
\text { 2. } & \text { Tokoh adat } \\
\text { 3. Sistem kekerabatan } \\
\text { 4. Institusi keagamaan } \\
\text { 5. Institusi ekonomi lokal }\end{array}$ \\
\hline & & $\begin{array}{l}\text { 4.Sistem } \\
\text { Teknologi } \\
\text { Tradisional }\end{array}$ & $\begin{array}{l}\text { 1. Kojow: tombak panjang } \\
\text { 2. Sumpitan: terbuat dari bambu keras, panjang } 1 \text { depa } \\
\text { 3. Timpo-timpo: sejenis perangkat yang terbuat dari batang kayu } \\
\text { 4. Jaring rusa } \\
\text { 5. Jerat: terbuat dari tali atau rotan } \\
\text { 6. Perangkap: berbentuk kurungan dapat diangkat-angkat } \\
\text { 7. Kepok: tempat menyimpan padi } \\
\text { 8. Sangkar: tempat menyimpan ikan atau ayam, burung } \\
\text { 9. Labu: tempat air dari buah labu yang dikeringkan } \\
\text { 10. Bakul: tempat bahan makanan sehari-hari yang terbuat dari } \\
\text { pandan anyaman } \\
\text { 11. Sumpik: semacam karung yang terbuat dari pandan anyaman } \\
\text { 12. Lesung: penumbuk padi } \\
\text { 13. Tempayan: tempat air dari tembikar } \\
\text { 14. Ago: tempat membawa alat-alat pertanian yang terbuat dari } \\
\text { rotan } \\
\text { 15. Tikar: tempat alas duduk/tidur terbuat dari pandan } \\
\text { 16. Terapang, sundang, perisai, keris, lelo, penggiling sagu, getah, } \\
\text { gula }\end{array}$ \\
\hline
\end{tabular}

Sumber : Wawancara dan Data Interpretasi Lapangan (2014)

hutan. Sistem penggunaan lahan merupakan warisan adat yang sampai sekarang masih di pertahankan oleh beberapa kelompok adat masyarakat Rokan Hilir.

Secara tradisional, masyarakat Melayu memiliki istilah-istilah tertentu untuk membagi jenis-jenis tentang kearifan lokal. Ini dimaksudkan agar jenis-jenis kearifan lokal dimanfaatkan sesuai dengan fungsi dan kegunaannya masing-masing. Pengetahuan tentang jenis-jenis kearifan lingkungan ini dijadikan dasar tindakan pemanfaatan dan pengelolaan sumberdaya alam yang terkandung didalamnya.

Imbo atau rimba merupakan sebutan untuk hutan secara keseluruhan yang diberikan oleh masyarakat Rokan Hilir. Rimba merupakan tempat mereka untuk memenuhi kebutuhan hidup sehari-hari mulai dari kebutuhan sandang, pangan, papan dan tempat melaksanakan adat istiadat mereka. Di rimbalah mereka meramu, menyuluh dan membuka ladang. Segala bentuk aktifitas kebudayaan dilakukan di rimba. 
Husni Thamrin, Zulfan Saam; ECO-Religio-Culture Suatu Alternatif Pengelolaan Lingkungan

Ada juga ladang yang telah ditinggalkan oleh masyarakat Melayu karena telah mengalami penurunan hasil produksi. Menurut penuturan informan Hasan Basri (57 tahun, di Bangko) sisa ladang ini atau disebut sosab masih menyisakan sumber pangan bagi mereka, tetapi tidak dapat memenuhi semua kebutuhan anggota kelompokmereka. Sumber pangan tersebut berupa umbiumbian yang akan terus hidup tanpa adanya pengelolaan yang intensif, pisang, dan tumbuh-tumbuhan yang berumur pendek lainnya.

Apabila ladang mereka mengalami maso koing ataupaceklik, maka sisa ladang merupakan tempat yang pertama kali dituju untuk mengambil umbi-umbian guna memenuhi kebutuhan pangan. Mereka tidak pernah melakukan perawatan pada tanamantanaman yang tumbuh di tempat sisa ladang. Mereka hanya membiarkannya tumbuh begitu saja. Sosap juga merupakan tempat tumbuhnya tanaman obat-obatan.

Di samping sosap mereka mengenal beluka(r) merupakan sosap yang telah lama ditinggal masyarakat Rokan Hilir. Beluka tidak menghasilkan sumber makanan pokok, tetapi masih menyisakan tanaman buah-buahan dan berbagai jenis tanaman yang sangat dibutuhkan mereka seperti tanaman obat. Biasanya beluka ini dalam penuturan informan Hasan tersebut ditumbuhi pohon durian, tampui, rambai, duku hutan, kelubi, salak hutan, rambutan hutan, cempodak hutan, petai, berbagai jenis pohon sialang, pohon pulai, giam, gaharu, meranti, pinang merah, rotan, manau dan upih-upih.

Beluka merupakan jenis hutan sekunder yang vegetasinya didominasi oleh tumbuhan semak-semak. Jenis-jenis pohon besar tidak banyak dijumpai di lokasi ini. Hal ini dikarenakan pohon-pohon tersebut telah lama ditebang guna membersihkan lahan perladangan mereka diwaktu lampau.
Peramuan hasil hutan non kayu banyak dilakukan di daerah ini mengingat banyaknya dijumpai hasil hutan non kayu tersebut. Beluka pada tanah adatmerupakan daerah yang selalu di kunjungi masyarakat Melayu sehingga mereka dapat mengetahui hasil hutan yang sudah layak dipanen. Hutan adat memiliki fungsi yang sangat besar bagi masyarakat Rokan Hilir, selain berperan sebagai sumber makanan berupa buahbuahan dan beberapa jenis kayu yang sangat bermanfaat seperti pohon sialang juga berperan sebagai tanah yang di sakralkan oleh masyarakat adat

Hutan adat yang kini disebut hutan simpanan desa dimanfaatkan masyarakat Melayuuntuk berladang yang tersebar di kawasan Kecamatan Kubu. Hutan adatdapat kita jumpai di pinggir-pinggir kawasan kampung di Rokan Hilir. Hal ini dikarenakan ruang hidup masyarakat Melayusemakin menyempit dan tidak lagi melakukan pembukaan hutan adatdi tengah-tengah hutan yang dahulunya mereka lakukan. Masyarakat Melayumulai sadar bahwa ladang-ladang yang dibuka di tengah hutan adat mengakibatkan hutan akan mengalami penurunan mutu dan mudahnya orang luar untuk masuk dan melakukan pembalakan liar (illegal logging). Dalam pengamatan penulis di lapangan (Agustus 2013) sangat disayangkan hutan adat yang seluas 100 ha telah dijual oleh oknum kepala desa dengan orang Batak, dari Sumatera Utara.

Hutan adatadalah kawasan hutan yang di tandai dengan vegetasi yang rapat dan relatif utuh atau merupakan hutan primer. Kawasan ini merupakan kawasan yang dipercaya oleh masyarakat Melayu merupakan tempat roh-roh menetap. Jika pemanfaatan yang dilakukan masyarakat Melayudi kawasan ini relatif berlebihan maka roh-roh atau dewa-dewi yang menetap di daerah tersebut akan marah dan mangakibatkan 
mereka terkena kutukan berupa wabah penyakit atau balo.

Dalam penuturan informan Datuk Samuel (73 tahun, di Kubu) hutan adat merupakan kawasan yang dimanfaatkan masyarakat Melayuuntuk meramu hasil hutan non kayu dan berburu. Hutan adat ini ditandai dengan vegetasi yang beraneka macam berupa semak belukar, rerumputan dan pepohonan yang tidak begitu rapat. Kawasan ini merupakan tempat binatang-binatang mencari makan dan membuat sarang. Populasi dan jenis binatang di daerah ini banyak sekali. Masyarakat Melayudapat menjumpai berbagai jenis binatang yang hidup di daerah ini.

Dalam kepercayaan Orang Rokan Hilirperbukitan yang curam dan daerah lembah-lembah dipinggiran sungai adalah tidak baik, baik untuk berladang dan menyuluh maupun untuk membuat tempat tinggal. Daerah ini dipercaya merupakan tempat orang bunyian atau hunian hantu-hantu. Mereka juga beranggapan bahwa di daerah ini jarang sekali dikunjungi binatang dan sangat sedikit jenis tumbuhan yang dapat dimanfaatkan. Intensitas kunjungan binatang yang kecil di daerah ini menyebabkan mereka tidak pernah memanfaatkannya sebagai tempat perburuan.

Hutan merupakan bagian hidup yang tidak terpisahkan dari kehidupan keseharian. Melalui ketersediaan lahan sumber daya hutan masyarakat Melayudapat mengerjakan pertanian ladang, menyuluh, meramu,dan menangkap ikan di sungai-sungai. Sumber daya hutan menyediakan lapangan pekerjaan yang terus dapat diperbaharui, asal dimanfaatkan sebatas kebutuhan subsistem dan memberikan waktu pemulihan alami atau dibantu oleh pemulihan yang dilakukan masyarakat Rokan Hilir. Penyediaan lapangan usaha dari lingkungan sekitar hutan mampu memenuhi ekonomi dan sumber pangan yang memberikan gizi dengan mutu yang tinggi. Sumber daya hutan menopang kebutuhan hidup dan kesejahteraan hidup masyarakat Rokan Hilir.

Hutan tanah adat Melayumemiliki ikatan yang sangat erat yang telah berlangsung sejak puluhan tahun yang lalu. Interaksi Orang Melayudengan hutan menumbuhkan nilai-nilai kearifan dalam pemanfaatan dan pengelolaan sumber daya hutan. Hasil interaksi tersebut membentuk suatu kebudayaan dan adat istiadat tersendiri dalam tatanan sosial budaya masyarakat Rokan Hilir. Hutan sebagai satu kesatuan lingkungan budaya yang menjadi tumpuan hidup (struggle life) untuk menunjang sistem kehidupannya. Hutan merupakan bagian integral dan tak terpisah dari kehidupan masyarakat Rokan Hilir. Hubungan interaksi antara masyarakat Melayu dan hutan telah berlangsung sangat lama secara lintas generasi. Untuk mempertahankan kehidupannya, masyarakat Melayu memanfaatkan dan mengelola sumber daya hutan secara arif. Hutan menjadi sumber pemenuhan kebutuhan hidup, baik pemenuhan kebutuhan ragawi maupun kebutuhan rohani.

Hutan adat sebagai sumber kehidupan masyarakat Melayu ditunjukkan dari ketergantungan mereka dalam hal pemenuhan kebutuhan tempat tinggal, lapangan pekerjaan maupun ketersediaan pangan. Masyarakat Melayumembangun tempat tinggal berupa rumah sebagai tempat bermukim dan melanjutkan generasi serta sebagai tempat sosialisasi dan pewarisan budaya dari generasi ke generasi. Hutan mempunyai hubungan dialektika kehidupan masyarakat Rokan Hilir. Hutan dipersiapkan sebagai tempat berkumpulnya makhluk halus dan benda-benda yang mempunyai nilai mistis yang menghubungkan dunia nyata dengan dunia gaib. Ekosistem hutan adalah ciptaan Tuhan yang bersemayam di pohon-pohon besar, batu-batu, sungai, tanah, air, dan udara. 
Husni Thamrin, Zulfan Saam; ECO-Religio-Culture Suatu Alternatif Pengelolaan Lingkungan

Ekosistem hutan harus dijaga dan tidak dimanfaatkan secara sembarangan. Hal ini akan menimbulkan bencana atau kutukan yang berasal dari supranatural apabila melanggar aturan yang telah ada.

Secara khusus, hampir dalam semua masyarakat adat dan tanah adatnya mempunyai peranan sangat penting, dan mempunyai nilai-nilai yang sangat tinggi. Tanah adat bagi masyarakat Melayuadalah sumber kehidupan, baik bagi masyarakatnya maupun bagi semua makhluk hidup lain. Bahkan dalam pandangan Keraf (2010) tanah adat mempunyai arti tertentu, tanah adat bukan sekadar sumber kehidupan. la adalah kehidupan itu sendiri. la adalah ibu yang memberi hidup dan memancarkan kehidupan. la memberi makna kepada kehidupan. Ini ditemukan baik di India, Indonesia, Australia maupun dalam banyak suku asli lainnya di seluruh dunia.

Tanah adat Melayu mempunyai dan memberi makna ekologis, sosial, ekonomi, politk, spiritual dan akhlak bagi manusia dan makhluk hidup lain. Seperti dikatakan oleh Vandana Shiva, "tanah bukan sekadar rahim bagi reproduksi kehidupan biologis, melainkan juga reproduksi kehidupan budaya dan spiritual(Keraf, 2010).

Dalam pandangan masyarakat adat Melayubinatang dan semua makhluk hidup lain merupakan bagian dari kehidupan kosmis, relasi dan kewajiban manusia terhadap semua makhluk hidup dipahami sebagai relasi dan kewajiban terhadap kerabat alam dan Allah yang Maha Kuasa. Cara pandang dan penghayatan seperti ini terungkap dalam Al-Qur'an:

"Dan kamu lihat bumi ini kering, kemudian apabila Kami telah menurunkan air diatasnya, hiduplah bumi itu dan suburlah dan menumbuhkan berbagai macam tumbuhtumbuhan yang indah. Yang demikian itu, karena sesungguhnya Allah, Dia lah yang hak dan sesungguhnya Dia lah yang menghidupkan segala yang mati dan sesungguhnya Allah Maha Kuasa atas segala sesuatu." QS. al-Haj (22): 5-6

Dalam ayat ini mengungkapkan semua kehidupan di alam semesta didunia dan akhirat sebagai relasi kontinuitas eskatologis, sekaligus mengungkapkan sikap hormat dan cinta mereka kepada semua kehidupan yang membentuk sebuah "jaring kehidupan" yang terkait satu sama lain di dalam komunitas ekoreligius.

Penghayatan yang serupa ditemukan pada suku tradisional yang menyebut dan menyapa binatang, pohon atau tempat sakral tertentusebagai "belle" (kakek/nenek). Relasi dengan semua kehidupan lain ini sangat penting, karena semua kehidupan ini menjadi tumpuan hidupnya. Keberhasilan panen atau penangkapan ikan sangat tergantung dari sejauh mana relasi dengan semua kehidupan tadi dipelihara secara baik. Relasi dengan alam, dan makhluk hidup lain, biasanya dijaga baik melalui pemeliharaan terhadap alam yang dituntun oleh berbagai tabu, maupun melalui komunikasi yang diperantarai oleh rohroh halus.

Pemahaman masyarakat adat Melayupercaya bahwa semua ciptaan merupakan satu kesatuan menyeluruh yang harmonis. Makhluk yang sakral dan mitologis ada di mana-mana, dan semua elemen dalam alambinatang, tumbuhan, hutan, gunung, sungaimempunyai jiwa. Tetapi, lebih dari sekadar memiliki jiwa, semuanya mempunyai kepribadian, masing-masing ada penunggunya dengan kepribadian atau karakternya sendiri-sendiri.

Ini tidak lalu berarti, binatang dan tumbuhan tidak boleh diambil dan dimanfaatkan demi kebutuhan hidup manusia. Masyarakat adat Melayu Melayujustru menggantungkan hidupnya pada binatang 
dan tumbuhan, pada alam. Bahkan kegiatan berburu, menangkap ikan dan mengumpulkan hasil hutan adalah praktik kehidupan sehari-hari. Hanya saja, semua kegiatan ini ditempatkan dalam konteks keterkaitan seluruh kehidupan dalam sakralnya. Maka, semua aktivitas itu diliputi oleh tabu dan upacara ekoreligius untuk mengekspresikan sikap hormat dan apresiasi akan nilai kehidupan dari makhluk lain tersebut. Ini juga dipahami sebagai semacam "minta izin" yang sekaligus berarti pengluhuran terhadap makna kehidupan itu sendiri, yang dikorbankan demi kehidupan makhluk lain (manusia).Melalui jalan itu, relasi dan keterkaitan "jaring kehidupan" dapat berjalan secara berkesinambungan.

Hal ini tentu berbeda sekali dengan kegiatan berburu pada masyarakat modern saat ini. Kegiatan berburu masyarakat modern tidak ditempatkan dalam konteks sakralitas alam dan tidak ditempatkan dalam keterkaitan di antara semua makhluk hidup. Berburu dalam masyarakat modern Melayuadalah aktivitas antroposentris yang mana menegaskan heroisme dan keunggulan manusia atas alam. Demikian pula, ketika masyarakat modern Melayu memelihara dan menyayangi binatang piaraan, sikap sayang tersebut tidak dipraktekkan demi binatang tersebut, tetapi demi kepuasan afeksi manusia modern. Dalam praktik tersebut binatang hanyalah obyek bagi kepuasan manusia.

Bagi masyarakat adat, Melayurespek atau sikap hormat kepada kehidupan, baik pada manusia maupun pada makhluk lain dan Sang Pencipta merupakan sebuah hukum moral, hukum moral kehidupan itu sendiri. Karena, tanpa sikap hormat tidak mungkin akan ada harmoni dan komunitas yang berkelanjutan. Dari sikap hormat ini muncul harmoni, keadilan, hukum dan komunitas. Sikap hormat akan hukum kehidupan menjamin bahwa kehidupan akan berjalan terus tanpa henti. Hukum moral ini terejawantah dalam kodrat manusia, dalam kodrat alam, untuk dengan sendirinya secara alamiah saling menyayangi dan melindungi di antara semua kehidupan itu sendiri( Keraf, 2010).

Kearifan dalam menjaga tanah adat bagi masyarakat Melayumerupakan manifestasi bentuk pengetahuan, keyakinan, pemahaman atau wawasan serta adat kebiasaan atau akhlak yang menuntun perilaku manusia dalam kehidupan di dalam komunitas ekologis. Jadi, kearifan dalam tanah adat Melayu Melayubukan hanya menyangkut pengetahuan dan pemahaman masyarakat adat tentang manusia dan bagaimana relasi yang baik di antara manusia, melainkan juga menyangkut pengetahuan, pemahaman dan adat kebiasaan tentang manusia, alam, Allah dan bagaimana relasi di antara semua penghuni komunitas ekologis ini harus dibangun. Seluruh kearifanlokal ini dihayati, dipraktikkan, diajarkan dan diwariskan dari satu generasi ke generasi lain yang sekaligus membentuk pola perilaku manusia sehari-hari, baik terhadap sesama manusia maupun terhadap alam dan Allah SWT.

Hipotesis ini menunjukkan bahwa pertama, kearifan lingkungan dalam tanah adat Melayu Melayuadalah milik komunitasekologis religious. Demikian pula, yang dikenal sebagai pengetahuan tentang manusia, alam dan relasi dengan alam, manusia dan Allah juga milik komunitas yang terintegrasi. Tidak ada pengetahuan atau kearifan tradisional yang bersifat parsial. Dalam pandangan antroposentrik yang hanya mengakui kepemilikan individual atas pengetahuan dan teknologi dengan sadar menegasi dan menghancurkan eksistensi kearifan dan pengetahuan lokal. Dengan tidak mengakui kepemilikan bersama atas kearifan lokal secara tidak langsung mau diktakan bahwa 
kearifan lokal itu tidak ada. Padahal, kearifan lokal Melayu Melayuitu memang benar-benar ada, tetapi dalam bentuk collective and communal wisdom. Kearifan tersebut dimiliki dan disebarluaskan secara kolektif-kolegial bagi semua anggota komunitas masyarakat adat Rokan Hilir. la terbuka untuk diketahui, bahkan harus diajarkan secara terbuka untuk dimiliki dan dihayati oleh semua anggota komunitas adat lainnya yang sejenis sebagai landasan etik untuk pengelolaan lingkungan secara berkelanjutan.

Kedua, kearifan lingkungan dalam tanah adatmempunyai makna pengetahuan tradisional masyarakat adat Rokan Hilir, lebih bersifat praktis, atau "pengetahuan bagaimana." Pengetahuan dan kearifan masyarakat adat Melayu Melayuadalah pengetahuan bagaimana hidup secara baik dalam komunitas ekologis, sosial, ekonomi, eligius, moral dan politik, sehingga menyangkut bagaimana berhubungan secara holistik dengan semua isi alam, manusia dan supranatural.

Nilai yang terkandung dalam tanah adat Melayujuga mencakup bagaimana memperlakukan setiap bagian dan kehidupan dalam alam sedemikian rupa, baik untuk mempertahankan kehidupan masing-masing flora, fauna, hutan, sungai, dan danau maupun untuk mempertahankan seluruh kehidupan di alam itu sendiri. Itu sebabnya, selalu ada berbagai aturan yang sebagian besar dalam bentuk larangan atau tabutentang bagaimana menjalankan aktivitas kehidupan tertentu di alam ini: bagaimana bertani secara baik, berburu secara baik, menangkap ikan secara baik, menebang pohon, memelihara sungai,memelihara tanah, danau, laut,selat, bepergian dan sebagainya. Masyarakat adat ini tahu betul kapan waktu yang tepat untuk melakukan perjalanan jauh, membuka ladang, pergi ke laut menangkapikan, berburu dan sebagainya. Semuanya ada ketentuan sebagai pengetahuan praktis serta norma yang menuntun pelaksanaannya.

Ketiga, nilai yang terkandung dalam tanah adat Melayu mencakup nilai kearifan lingkungan bersifat holistik, karena menyangkut pengetahuan dan pemahaman tentang seluruh kehidupan dengan segala relasinya di alam semesta. Alam adalah "titipan Allah" yang lebih luas dari sekadar jumlah keseluruhan bagian yang terpisah satu sama lain. Alam adalah rangkaian relasi manusia-alam-supranatural yang terkait satu sama lain, sehingga pemahaman dan pengetahuan tentang alam harus merupakan suatu pengetahuan menyeluruh yang bersifat cosmologis-spritual-religius. Hubungan manusia-alam-Allah adalah hubungan yang sempurna.Terjadinya kerusakan di muka bumi adalah ulah prilaku manusia yang serakah. Hal ini sejalan dengan ungkapan petatah petitih Melayu dan Firman Allah Swt dalam Al-Qur'an dalam surat Rum (30): 41:

"Telah nampak kerusakan di darat dan di laut disebabkan karena perbuatan tangan manusia supaya Allah merasakan kepada mereka sebahagian dari (akibat) perbuatan mereka, agar mereka kembali (kejalan yang benar)".

Demikian pula, subyek manusia Melayu Melayuyang memahami alam adalah subyek yang terlibat dalam manusia-alam-Allah .Alam tidak dilihat semata-mata sebagai obyek yang ditangkap dan dianalisis secara clara et distincta sebagaimana pada Descartes. Alam justru dipahami sebagai penuh dengan nilai dan pesan moral. Alam mengirim pesan dan perintah moral untuk dipatuhi manusia: termasuk pesan moral berupa hormati kehidupan. Karena alam adalah kerabat, pada dirinya sendiri ada nilai yang harus dipatuhi (Keraf, 2010).

Keempat, nilai yang terkandung dalam tanah adat adalah kearifan lingkungan 
masyarakat adat Melayu Melayu memahami semua aktivitasnya sebagai aktivitas ecoculture-religious. Kegiatan bertani, berburu dan menangkap ikan bukanlah sekadar aktivitas ilmiah berupa penerapan pengetahuan ilmiah tentang dan sesuai dengan alam, yang dituntun oleh prinsipprinsip dan pemahaman ilmiah yang rasional. Aktivitas tersebut adalah aktivitas ecoreligius yang dituntun dan didasarkan pada prinsip atau tabu-tabu sakral dan magis yang bersumber dari kearifan lokal mayarakat Rokan Hilir. Aktivitas tersebut memang tidak dapat dijelaskan secara rasional menurut ukuran ilmu pengetahuan positivistik. la hanya bisa dipahami dalam kerangka kearifan tradisional dalam perspektif antroposentrik. Secara tradisi orang Melayusetiap tahap aktivitas menangkap ikan,berburu, dan berladang harus didahului oleh doa, tidak bisa dijelaskan secara ilmiah rasional. Orang Melayu Melayudalam melakukan aktivitas menangkap ikan, mengambil lebah, dan menanam padi tidak boleh berkata takabur, menggunakan kata-kata tidak senonoh, dan tidak boleh ada dendam dan permusuhan di dalam masyarakat, memang tidak dapat dijelaskan secara paradigma positivistik.Apa hubungan antara dendam terhadap kerabat lain dengan kegagalan dalam berburu ikan,menanman padi, menjerat hewan atau dengan kecelakaan dalam kegitan tersebut tidak bisa dijelaskan oleh pengetahuan ilmiah rasional positivistik. Tidak ada hubungan sebab dan akibat (hukum kausalitas) di antara kedua peristiwa itu yang bisa menjelaskan mengapa mereka gagal aktivitas tersebut. Semua ini hanya bisa dipahami dalam kerangka kearifan masyarakat adat bahwa aktivitas mereka adalah implementasi dan perwujudan kearifan lokal mereka tentang manusia, alam dan hubungan di antara mereka dengan alam-manusia dan supranatural. Ini hanya bisa dipahami dalam konteks bahwa aktivitas mereka adalah aktivitas eco-religious.

Kelima, berbeda dengan pandangan antroposentrik yang mengklaim dirinya sebagai universal, kearifan tradisional bersifat lokal, karena terkait dengan tempat yang khusus dan konkret. Pandangan eco-culture memandang kearifan lingkungan dan pengetahuan tradisional selalu menyangkut pribadi manusia yang partikular (komunitas masyarakat adat itu sendiri), alam (di sekitar tempat tinggalnya, bahkan tentang pohon, sungai, hewan, danau, dan laut yang partikular), dan relasinya dengan alam itu. Tetapi, karena manusia dan alam bersifat universal, kearifan dan pengetahuan tradisionaldengan tidak direkayasa punmenjadi universal pada dirinya sendiri. Kendati tidak memiliki rumusan universal sebagaimana dikenal dalam ilmu pengetahuan modern, kearifan tradisional ternyata ditemukan di semua masyarakat adat atau suku asli di seluruh dunia, dengan substansi yang sama. Ada praktik kearifan dan pengetahuan yang sama, baik dalam dimensi teknis (tata cara teknis) maupun dalam dimensi moralnya muatan moral yang mengelilingi tata cara teknis.

Kearifan lokal masyarakat Melayu mengalami erosi, atau kritis sebagian terdegradasi yang disebabkan beberapa factor. Pertama, terjadi proses desakralisasi alam oleh invasi dan dominasi kegiatan ekonomi yang antroposentrik dan teknologi modern. Alam yang dipahami sebagai sakral oleh masyarakat adat Melayudan menyimpan sejuta misteri yang sulit bisa dijelaskan dengan menggunakan akal budi, sehingga membangkitkan sikap kagum penuh rasa hormat, kehilangan sakralitas dan misterinya dalam paradigma antroposentrik dan teknologi modern. Dalam paradigma antroposentrik yang positivistik-kapitalistik, alam dipahami sebagai sekadar fakta yang profan tanpa 
Husni Thamrin, Zulfan Saam; ECO-Religio-Culture Suatu Alternatif Pengelolaan Lingkungan

getaran sacral-magis-religius, tanpa nilai dan muatan moral sama sekali. Alam direduksi sekadar sebagai obyek dan fakta yang bisa dipilah-pilah, dianalisis dan dijelaskan secara ilmiah-rasional. Fenomena alam yang dipahami sebagai misteri ternyata dalam perspektif ilmu pengetahuan modern hanya problem yang bisa dijelaskan secara ilmiah dan rasional: bahwa ternyata alam dan semua kehidupan serta benda di dalamnya terdiri dari berbagai unsur kimia, fisika, dan biologi yang bisa diuraikan. Interaksi berbagai unsur kimia, fisika, dan biologi tersebutlah yang menimbulkan berbagai fenomena alamyang menimbulkan rasa kagum, takut, dan takjub. Ternyata semua hal itu sebagai sebuah fenomena alam yang rasional-ilmiah.

Bersamaan dengan itu, kekuatan magik alam menjadi hilang. Terjadi desakralisasi alam, yang membuat alam tidak lagi menarik untuk dihormati, disembah, dan dipelihara penuh takjub. Maka, manusia pun melihat dirinya begitu agung dan superior berhadapan dengan alam yang tidak berarti sama sekali. Oleh karena itu, sikap hormat, perilaku merawat, mencintai dan menjaga keharmonisan atau hubungan baik dengan alam menjadi tidak relevan dan tidak punya tempat lagi. "Desakralisasi(alam) terjadi melalui perubahan makna ruang (space). Ruang yang sakral, pusat segala makna dan kehidupan, sumber ekologis dari keberlangsungan hidup, diubah menjadi sekadar tempat (site), lokasi dalam pandangan antroposentrik. Padahal dalam pandanganorang Melayu hubungan manusiaalam-Allah adalah relasi metafisis religious yang sakral.Hal ini dapat kita lihat pada pembahasan terdahulu banyak pantang larang dan petuah yang esensinya bersumber dari Al-Quran dapat dilihat relasi dengan alam dalam surat al-Baqarah (2): 164.

Sesungguhnya dalam penciptaan langit dan bumi, silih bergantinya malam dan siang, bahtera yang berlayar di laut membawa apa yang berguna bagi manusia, dan apa yang Allah turunkan dari langit berupa air, lalu dengan air itu Dia hidupkan bumi sesudah mati (kering) nya dan Dia sebarkan di bumi itu segala jenis hewan, dan pengisaran angin dan awan yang dikendalikan antara langit dan bumi; Sungguh (terdapat) tanda-tanda (keesaan dan kebesaran Allah) bagi kaum yang memikirkan.

Kedua, regulasi hukum dan kebijakan hanya untuk kepentingan nilai ekonomis kapitalistik telah memarjinalkan keberadaan tanah adat orang Melayu.

\section{Kesimpulan}

Dalam hal pengaturan dan eksistensi pengelolaan lingkungan hidup perlu menerapkan paradigma eco-religio-culture sebagai sebuah koseptual dan kebijakan untuk melestarikan lingkungan yang berkelanjutan. Dengan konsep ini masyarakat lokal lebih sustainable, mempunyai identitas, dan memiliki kearifan ekologis, religius, sosial dan ekonomis. Terjadinya degradasi lingkungan dan marjinalisasi masyakat adat dewasa ini sebagai akibat pandangan yang antroposentrik, manusia cendrung mengekploitasi alam tanpa ada batasnya.

Fungsi eco-religio-culture dalam pelestarian lingkungan hidup mencakup fungsi sosio-kultural-kosmologis ekologis, kosmologis religius sosia-ekonomis-metafisis,eco-religius dan eco-culture. Paradigm ini mampu mempertahankan dan menjaga kelestarian lingkungan hidupnya. Untuk mengatasi persoalan degradasi lingkungan hidup dan marjinalisasi masyarakat lokal perlu merevitalisasi kearifan lingkungan masyarakat lokal dengan cara merobah pandang dari antroposentris ke eco-religio culture.

Terjadinya degradasi lingkungan dan marjinalisasi masyarakat lokal disebabkan 
oleh cara pandang yang antroposentrik yang berbeda dengan cara pandang eco-religiocultureyang melihat komunitas masyarakat adat adalah komunitas ekologis, bukan hanya komunitas sosial manusia sebagaimana dipahami cara pandang antroposentrik. Dalam pandangan eco-religio -culture masyarakat lokalmerupakan bagian integral dari komunitas ekologis, komunitas alam dan komunitas metafisis-religius. Masyarakat lokal berkembang menjadi dirinya, baik secara individual maupun secara kelompok, dalam ikatan dan relasi dengan alam semesta seluruhnya, dengan seluruh makhluk di alam semesta serta berintegrasi dengan zat yang metafisis-religius-cultural dalam pelestarian lingkungan.

\section{DAFTAR PUSTAKA}

\section{A. Jurnal}

Abdul Hak, Rifardi dan Yusni Ikhwan Sireger,Kajian Kapasitas Asimilasi Perairan Sungai Rokan Desa Rantau Bais Kabupaten Rokan Hilir Propinsi Riau, Jurnal Kajian Lingkungan UR Vol 1 No 1 Januari 2013:23-33.

Budi Darmawan, Zulkarnaini dan Zulfan Saam, Hubungan Pengetahuan, Sikap, Prilaku dan Peranserta dengan Kesadaran Lingkungan Hidup Serta Kesanggupan Membayar Masyarakat Sekitar Bantaran Sungai di Kota Pekanbaru. Jurnal Ilmu Lingkungan (Journal of Enviromental Science) PPS UR Vol.4 No.2 September 2010: 103-116.

Burnados, Caritas Bowo Murdiati,Konsep Keadilan Sosial yang Berwawasan Ekologis Menurut Vandana Shiva, Jurnal Fundamental , Vol 17, No 2 : 15-37.
Fifin Arfiana Jogasara, Zulkarnaini dan Zulfan Saam, Analisis Faktor-Faktor yang Mempengaruhi Intensitas Konflik antar Gajah dan Manusia di Kecamatan Mandau dan Pinggir Kabupaten Bengkalis.Jurnal IImu Lingkungan PPS UR Vol.6 No.1 Maret 2012: 6381.

Husni Thamrin, Kearifan Lokal dalam Pelestarian Lingkungan ,Jurnal Kutubkhanah LP2M UIN SUSKA RIAU , Vol.16 No 1 Janauari-Juni 2013:46-59.

Husni Thamrin, Paradigma Pengelolaan Lingkungan : Antropocentric Versus Ekocentrik, Jurnal Kutubkhanah,LP2M UIN SUSKA RIAU Vol.16.No.2.JuliDesember 2013 :61-72.

Lestuti Abu Bakar, Revitalisasi Hukum Adat sebagai Sumber Hukum dalam Membangun Sistem Hukum Indonesia, Jurnal Dinamika Hukum UNPAD , Vol,13 No.2 Mei 2013 : 320331

Noviawati Riza,Thamrin dan Syofyan Husain Sireger. Analisis Status Kualitas Air Anak-anak Sungai Singingi Sekitar Tambang Batu Bara di Kuantan Singingi. Jurnal Ilmu Lingkungan PPS UR.Vol.6,No.2 September 2012.

Nurman, Zulfan Saam dan Thamrin, Kearifan Lokal Masyarakat Talang Mamak dalam Berladang, Jurnal IImu Lingkungan PPS UR Vol.2 No,1 Januari 2014: 27-48

Rasul Hamidi, Zulkarnaini dan Zulfan Saam, Analisa Sosial Ekonomi Masyarakat Desa Hutan Pascakegiatan HPH PT.Siak Raya Timber di Kabupaten Pelalawan, Propinsi Riau .Jurnal IImu Lingkungan Vol.5 Nomor 2 September 2011 : 130-148.

Suparmini, Sriadi Setyawati dan Dyah Respati, Pelestaruan Lingkungan 
Husni Thamrin, Zulfan Saam; ECO-Religio-Culture Suatu Alternatif Pengelolaan Lingkungan

Masyarakat Baduy Berbasiskan Kearifan Lokal, Jurnal Penelitian Humaniora, Vol.18, No. 1 April 2013 : 8-22

Suwandi,Tukiman Taruna,Hartuti Purnaweni .Kearifan Lokal dalam Melestarikan Mata Air (Studi Kasus di Desa Punwogondo,Kecamatan Boja Kabupaten Kendal) ,Jurnal IImu Lingkungan UNDIP Vol.9,Issue 2: 6368 (2011)

Syahyuti , Nilai-Nilai Kearifan Pada Konsep Penguasaan Tanah Menurut Hukum Adat Indonesia Forum Penelitian Agro Ekonomi, Vol 24, No 1 ,Juli 2006: 1417

Syaifuddin,Sujianto dan Thamrin,Partisispasi Masyarakat dalam Pembangunan Prasarana Lingkungan Melalui Program Dana Hibah Khusus (Suatu Kajian Bantuan Dana Pedesaan di Kecamatan Kandis Kab.Siak. Jurnal Ilmu Lingkungan. Vol.7 No.1 Maret 2013:95-102.

Tengku Evayanti, Zulkarnaini dan Thamrin, Partisispasi Organisasi Masyarakat Peduli Api (MPA) terhadap Pencegahan dan Pengendalian Kebakaran Hutan dan Lahan di Kabupaten Pelalawan

Veraliza, Zulfan Saam dan Thamrin, Manajemen Kearifan Lokal lubuk Larangan Desa Pengkalan Indarung Kabupaten Kuantan Singingi Propinsi Riau ,Jurnal Ilmu Lingkungan ,Vol 8,Nomor 2 September 2014 : 180196.

Zulfan Saam dan Raja Arlizon, Kearifan Lokal dalam Budaya Perkandangan di Kabupaten Kuantan Singingi, Jurnal Ilmu Lingkungan , Vol.5 No 1 Maret 2011 : 10-20.
B. Buku..

Effenddy, T 2004. Tunjuk Ajar Melayu (ButirButir Budaya Melayu Riau). Yogyakarta, Adicita Karya.

Haar, T B,. 1931 Het Adatrecht van Naderlandsch -Indie in Watenschap, Practij en Onderwijs

Husni .T 2012 Eco-Culture Orang Melayu, Pekanbaru,LPP UIN SUSKA RIAU.

2003 Sakai : Kekuasaan,Pembangunan dan Marginalisasi, Pekanbaru, Gagasan Press.

Keraf, A.S. 2010, Etika Lingkungan. Jakarta, Kompas.

Koentjaraningrat. 1993 Masyarakat Terasing di Indonesia,Jakarta, Yayasan Obor Indonesia. 1990. Pengantar IImu Antropologi. Jakarta, Rineka Cipta.

Laretna . 2009. Human Ecology. California, Wadswordht Publishing Co, Inc.

Moran, E.F.1993. The Ecosystem Approach in Anthropology. USA, The University of Michigan Press.

Mugnisjah. $2001 \quad$ Lingkungan:

Sumberdaya Alam dan Kependudukan dalam Pembangunan. Jakarta, Universitas Indonesia.

Naess,A 1973 The Deep Ecological Movement. Some Philoshopical Aspect. Boston,Shambala.

Neoloka, A 2008. Kesadaran Lingkungan, Jakarta, Reneka Cipta.

Northbourne,L 1940 The Future of AgriEnvironmental System. Cambridge Book

Redcliff, M $1990 \quad$ Sustainable

Development: Exploringthe Contradiction, London and New York, Routledge, 
AL-Fikra: Jurnal IImiah Keislaman, Vol. 15, No. 1 , Januari - Juni 2016

Salim, E 2010 Ratusan Bangsa Merusak Satu Bumi, Jakarta, Kompas

Sjakowi ,F(et.all) 2007 Kualitas Lingkungan Hidup Sumatera 2007, Pekanbaru, KNLH RI , Regional Sumatera

Smith,A 1979 The Theory of Moral Sentiment, Oxford, Clarendon Press.

Spradley and McCurdy. 1987. Confirmity and Conflict. USA, Little, Brown and Compan.

Susanto, A 1984 Sosiologi Pembangunan. Bandung, Bina Cipta

Syarkowi,F (dkk) 2007 Kuaitas Lingkungan Hidup Sumatera, Pekanbaru,PPLHR Sumatera

Thalib, S 1985 Kebijakan dan Manajemen Lingkungan Hidup. Yogyakarta, Jalasutra.

1969.Environment and Cultural Behavior. University of Texas Press. USA.

Vayda, A.P. 1969. Environment and Cultural Behavior. University of Texas Press. USA

Vollenhoven, C1930 Het Adatrecht van Naderlandsch- Indi, Dell III dalam Soerjono Soekonto, Pokok-Pokok Hukum Adat ., Bandung 1984.

Wan Ghalib 1994 Serbaneka Hukum Adat Daerah Riau, Pekanbaru, LAM Riau.

Zein.R 1994. Tanah, Hutan dan Pembangunan. Pekanbaru: Universitas Islam Riau Press. 